\title{
TSH Signalling and Cancer
}

\section{revisão}

\section{Custodia García-JiMÉnEz PILAR SANTISTEBAN}

Departamento de Ciencias de la Salud III, Universidad Rey Juan Carlos (CG-J) and Instituto de Investigaciones Biomédicas "Alberto Sols" (PS), CSIC, Madrid, Spain.
Recebido em 08/03/07 Aceito em 17/03/07

\section{ABSTRACT}

Thyroid cancers are the most frequent endocrine neoplasms and mutations in the thyrotropin receptor (TSHR) are unusually frequent. Here we present the state-of-the-art concerning the role of TSHR in thyroid cancer and discuss it in light of the cancer stem cell theory or the classical view. We briefly review the gene and protein structure updating the cancer related TSHR mutations database. Intriguingly, hyperfunctioning TSHR mutants characterise differentiated cancers in contrast to undifferentiated thyroid cancers which very often bear silenced TSHR. It remains unclear whether TSHR alterations in thyroid cancers play a role in the onset or they appear as a consequence of genetic instability during evolution, but the presence of functional TSHR is exploited in therapy. We outline the signalling network build up in the thyrocyte between TSHR/PKA and other proliferative pathways such as Wnt, PI3K and MAPK. This network's integrity surely plays a role in the onset/evolution of thyroid cancer and needs further research. Lastly, future investigation of epigenetic events occurring at the TSHR and other loci may give better clues for molecular based therapy of undifferentiated thyroid carcinomas. Targeted demethylating agents, histone deacetylase inhibitors combined with retinoids and specific RNAis may help treatment in the future. (Arq Bras Endocrinol Metab 2007;51/5:654-671)

Keywords: Thyrotropin; Cancer; Signalling; MAPK; PI3K; PKA; Wnt; Thyroid; NIS

\section{RESUMO}

Sinalização de TSH e Câncer.

Os cânceres de tiróide são as neoplasias endócrinas mais frequentes e as mutações no receptor de tirotrofina (TSHR) são incomumente frequentes. Nesta revisão nós apresentamos o "estado da arte" com relação ao papel do TSHR no câncer de tiróide e o discutimos à luz da teoria da célula matriz do câncer ou a visão clássica. Revisamos brevemente a estrutura do gene e da proteína, atualizando a base de dados das mutações do TSHR relacionadas ao câncer. Curiosamente, mutações do TSHR com hiperfunção caracterizam cânceres diferenciados, em contraste com os cânceres de tiróide indiferenciados, os quais muito comumente mostram TSHR silenciados. Permanece obscuro se as alterações do TSHR em cânceres de tiróide têm algum papel no surgimento ou se elas aparecem como conseqüência da instabilidade genética durante seu desenvolvimento, mas a presença de TSHR funcional é explorada na terapia. Nós delineamos a rede de sinalizacão desenvolvida no tirócito entre TSHR/PKA e outras vias proliferativas como a Wnt, PI3k e MAPK. A integridade desta rede certamente tem um papel no surgimento/evolução do câncer de tiróide e necessita de novas pesquisas. Finalmente, novas investigacões sobre os eventos epigenéticos que ocorrem no TSHR e outros locais poderão trazer novas informações para uma terapia de base molecular nos carcinomas indiferenciados de tiróide. Agentes demetilantes direcionados, inibidores da histona-deacetilase, combinados com retinóides e RNAs específicos poderão auxiliar no tratamento futuro. (Arq Bras Endocrinol Metab 2007;51/5:654-671)

Descritores: Tirotrofina; Câncer; Sinalização; MAPK; PI3K; PKA; Wnt; Tireóide; NIS 


\section{THYROID CANCER: THE FREQUENCY, THE TYPES AND THE HYPOTHESIS}

$\mathrm{T}$ HYROID CANCER IS THE MOST frequent endocrine neoplasia and represents $1 \%$ of all cancers. According to the American Cancer Society, the frequency of thyroid cancer in USA was 100 per million population in 2003 , this incidence has been increasing at more than $5 \% / y r$ for a decade mostly due to increased diagnosis of small tumours (1). The annual mortality from thyroid cancer in 2003 was 5-6 per million. The discrepancy between incidence and mortality reflects the good prognosis for most thyroid cancers. Thyroid neoplasms may appear as benign nodules and adenomas or malignant tumours that can be from follicular cell origin: differentiated or undifferentiated; from the parafollicular C cells: medullary thyroid carcinoma (MTC), or else. Differentiated carcinomas are hystologically divided into papillary thyroid carcinoma (PTC) or follicular thyroid carcinoma (FTC). Detailed descriptions of this classification can be consulted elsewhere, i.e.: http://www.meb.uni-bonn.de/cancer. gov/CDR0000062913.html. Most thyroid tumours are sporadic as a consequence of somatic mutations, although hereditary thyroid carcinoma resulting from germinal mutations also occurs. Currently there are 2 hypotheses to explain thyroid cancer onset that are summarised in figure 1 . The classical view, depicted on the right, considers thyroid carcinoma as a complication of a pre-existing follicular adenoma accumulating mutations, which drive the progression through a dedifferentiation process. Differentiated thyrocytes

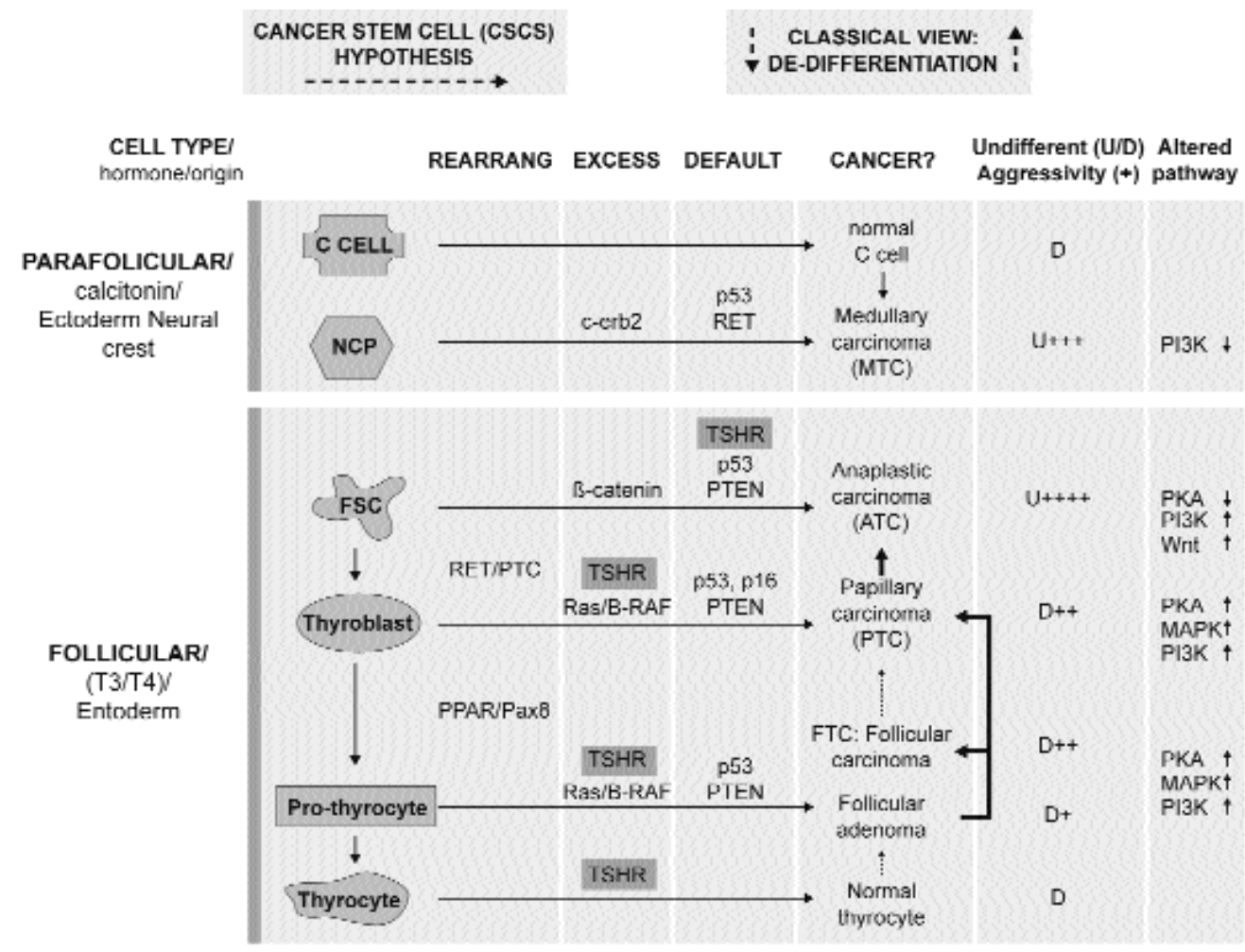

Figure 1. Two hypotheses to explain the onset of thyroid cancers: The Cancer Stem Cell hypothesis is represented on the left side: thyroid cell precursors may encounter mutations that deviates them from the normal differentiation path (vertical arrows) to develop into cancer stem cells (horizontal arrows). Thyroid cell precursors are abbreviated as NCP (Neural Crest Precursor) or FSP (Follicular Cells Precursor) to stress their different origin and characteristics. NCP migrate long distances to populate the thyroid and perhaps retain migrating (invasion) characteristics that enable them to become malignant with a smaller number of mutations. Mutations leading from every precursor to a different type of cancer are depicted on the horizontal arrows and are classified in (i) large chromosomal rearrangements, (ii) gain of function or excessive levels and (iii) silencing or disabling mutations in the proteins described. These mutations would lead from the precursor of a thyroid cell to a cancer cell (either latent or proliferative). The classical hypothesis is represented to the right of the horizontal arrows. This view assumes a process of de-differentiation represented by vertical arrows leading from differentiated thyrocyte at the bottom to the most undifferentiated: the Anaplastic Thyroid Cancer. The mutations described before would correspond now to the vertical arrows leading from one type of cancer to another. The column previous to the last represent the degree of differentiation (D) or undifferentiation (U) together with the aggressiveness of the cancer, which will be proportional to the number of " + " symbols. The last column resumes the signalling pathways represented by the stated protein mutants and whether the path is enhanced $(\uparrow)$ or interrupted $(\downarrow)$. 
TSHR Promoter

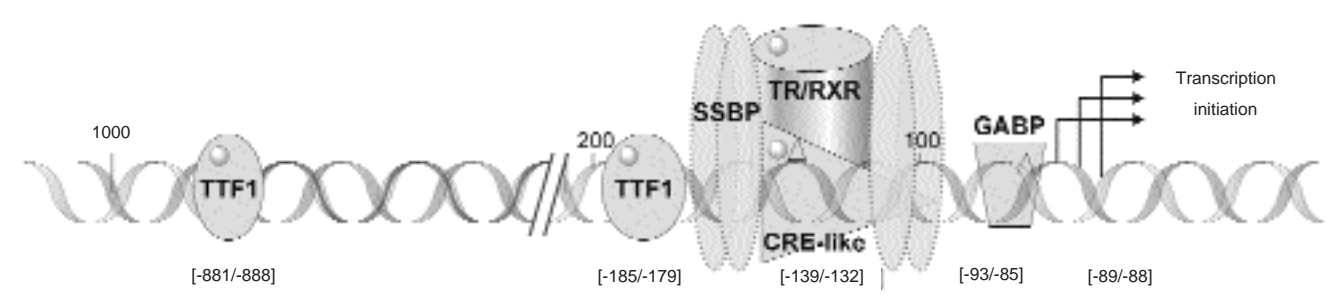

Figure 2. Known regulatory elements in the promoter of the TSHR: The promoter of TSHR is TATA-less and has multiple transcription start sites (arrows). GA-binding protein (GABP) dimers binding are sensitive to DNA methylation. The cAMP-response element (CRE-like) encompasses a constitutive enhancer that may bind the activators CREB or ATF2 and the repressor ICER. Binding of single strand binding protein (SSBP to the $5^{\prime}$ and $3^{\prime}$ flanking decanucleotide repeats modulates CRE-like site activity. The CRE-like site overlaps with a thyroid hormone response element. Binding of the heterodimer TR/RXR (thyroid hormone receptor and retinoid $X$ receptor) to this site represses transcription. The proximal promoter bears a binding site for the thyroid transcription factor 1 , TTF1 and there is at least another binding site at the far $5^{\prime}$ end. The positions in the promoter relative to the transcription start site appear depicted in brackets underneath the sites. Inside of a transcription factor indicates modulation via phosphorylation; $\Delta$ indicates modulation via methylation.

develop into differentiated thyroid cancer first, then undifferentiated and eventually to anaplastic thyroid carcinoma (ATC). Early thyroid tumour development correlates with mutation of signalling molecules encoded by five alternative genes: Ras, Ret, trk, gsp, and the TSH receptor; additional mutations in a genome caretaker gene such as p53 ensure genomic instability and would drive evolution towards ATC. Discrete de-differentiation steps difficult to explain are required and also it is rather infrequent that a benign adenoma evolves towards carcinoma; at present, it seems that most thyroid carcinomas are malignant from the onset. The original Ras and Ret mutations seen in FTC and PTC are hardly seen in ATC. These and other observations, particularly from Chernobyl irradiation studies, led to the formulation of an alternative hypothesis based in the existence of cancer stem cells (CSCs) and represented by the horizontal arrows from left to right in figure 1. The CSCs would be derived from embryonic thyroid stem cells, thyroblasts or pro-thyrocytes intermediaries in the pathway of differentiation accumulating mutations that lead to carcinogenesis. The CSCs hypothesis proposes that thyroid cancer develops as a consequence of a block in a differentiation step from any of these intermediaries rather than the process of de-differentiation contemplated by the classical view. The phenotype and incidence of a thyroid cancer type would remember those of the originating CSCs i.e.: the most undifferentiated and aggressive ATC would develop from the earliest and less abundant thyroblasts and would have the lower rate of incidence (2-4). The establishment of ES cell cultures able to differentiate into thyrocytes may clarify these views (5).

\section{THYROTROPIN BINDING TO ITS RECEPTOR IS THE MAIN STIMULUS FOR THYROCYTE PROLIFERATION}

Thyrotropin (TSH) secreted by the pituitary and bound to its receptor (TSHR) regulates thyroid growth and differentiation at late developmental stages but is not responsible for organogenesis or cell migration according to the phenotypes of the TSHR knockout mice $[(6,7)$, reviewed in $(8,9)]$. TSH promotes growth of the thyrocyte directly binding to its receptor and also indirectly, stimulating secretion of autocrine growth factors and amyloid precursors (1012 ) or the expression of growth factor receptors or of vascular endothelial growth factor, VEGF (13). Additional growth factors, such as insulin/IGF-1 or serum factors $(14,15)$ may be required for TSH induced proliferation of the thyrocyte. Thus, paracrine and autocrine factors secreted by follicular cells, the stromal apparatus and lymphocytes may be implicated in initiation and perpetuation of thyroid hyperplasia. TSH and its receptor are required not only for proliferation in the thyrocyte but also for the expression of differentiation markers such as thyroglobulin, thyroperoxidase or the $\mathrm{Na} / \mathrm{I}$ symporter (NIS) that is responsible for iodide uptake. These differentiation markers are required for the correct function of thyrocytes that is the synthesis of thyroid hormones. TSHR molecules in the membrane are quite stable and signalling in the thyrocyte will be controlled mainly through circulating TSH levels. TSH secretion is inhibited via negative feedback by thyroid hormones; in the absence of thyroid hormones there will be hyper-secretion of TSH and abnormal thyrocyte proliferation. 


\section{THE RELEVANCE OF TSHR FOR THE ONSET/ EVOLUTION OF THYROID CANCER IS UNCLEAR}

The importance of the TSHR signalling for the onset/evolution of thyroid cancer is supported by experiments in which regained expression of functional TSHR in a follicular thyroid cancer cell line (HTC) reduced angiogenesis and size of tumours of xenotransplanted HTC cells (16). Hyperactivated TSHR is commonly found in most adenomas, less common in differentiated carcinomas and the gene is silenced in undifferentiated cancers such as ATC (table 1 , see also figure 1). From the point of view of the classical de-differentiation hypotheses, these data from case studies are difficult to interpret; two mutation events on the TSHR gene are highly improbable, but would be required in the evolution from adenoma to ATC: first hyperactivating mutations in adenomas and later silencing in ATC. It would be easier to imagine that the TSHR gene being a susceptible candidate for mutation would mutate differently in different precursor cells undergoing transformation to CSCs. According to the CSCs hypothesis, only one alteration would be required at the TSHR locus to render each transformed phenotype. TSHR implication in the onset of thyroid cancer remains unclear but its functionality is important for thyroid function and treatment of thyroid cancers (see below). Additionally, TSHR may also be relevant in diagnosis. For example, based on the fact that most thyroid cancers still express the TSHR (17), its mRNA has been used as a highly sensitive and specific marker to detect thyroid cancer cells in peripheral blood (18). Differentiated thyroid cancer has better prognosis because the cells express NIS and can be targeted by radioactive ${ }^{131} \mathrm{I}$. TSH administration to thyroid cancer patients with functional TSHR ensures NIS expression, uptake of ${ }^{131} \mathrm{I}$ and the removal of malignant cells left over after ablation of the cancerous gland or nodule. Moreover, differentiated cancers produce thyroid hormones maintaining reduced pituitary TSH secretion. Undifferentiated thyroid carcinomas expressing TSHR but not NIS exist demonstrating that TSHR is required but not sufficient for NIS expression. These cancers are rather difficult to target because radioactive ${ }^{131}$ I will not be taken and insufficient thyroid hormone production will result in elevated TSH levels inducing further proliferation even in cells with diminished TSHR numbers.

Hence, signalling from the TSHR may play a role in the onset, evolution, diagnostic and therapies of thyroid cancer.

\section{THE TSHR GENE AND PROTEIN}

The TSHR cloned in 1989 (19-22) belongs to the family of the G protein coupled receptors (GPCR) and

Table 1. Update of "gain of function" mutations encountered at the TSHR in thyroid cancer and hyperthyroidism.

\begin{tabular}{|c|c|c|c|c|}
\hline AA-codon & LOCATION & PHENOTYPE & Comments & REF \\
\hline $\mathrm{S} 281 \mathrm{~N} / \mathrm{T} / \mathrm{G}$ & Ectodomain & In vitro studies & involved in $\mathrm{G}$ protein interaction & (131) \\
\hline G431S & TM1 & Hyperthyroidism & increased cAMP (Gas) and I3P(Gaq) & $(132,133)$ \\
\hline V463M & TM2 & hyperthyroidism & & $(134)$ \\
\hline $1486 \mathrm{~F}$ & ECL1 & adenoma/FTC & ECL1 is involved in silencing unstimulated TSHR & $(123,135)$ \\
\hline I486M & ECL1 & Follicular adenoma & & $(135)$ \\
\hline $\mathrm{S} 505 \mathrm{R} / \mathrm{N}$ & TM3 (GL) & Hyperthyroidism & Interactions TM3- TM5 are important for & $(114,136,137)$ \\
\hline V509A & TM3 (GL) & $\begin{array}{l}\text { Congenital Hyperthyroidism, } \\
\text { Adenoma, follicular cancer }\end{array}$ & $\begin{array}{l}\text { silencing the unstimulated receptor. } \\
\text { Increased cAMP (Gas) and I3P(Gaq). }\end{array}$ & (126) \\
\hline L512R & TM3 & PTC & & (138) \\
\hline L5120 & TM3 & $\begin{array}{l}\text { Hyperthyroidism } \\
\text { Multinodular goiter }\end{array}$ & gain of function & $(139) ;(140)$ \\
\hline V556F & TM4 & HTN & Increased cAMP (Gas) and I3P(Gaq) & (141) \\
\hline $\mathrm{I} 568 \mathrm{~V}$ & ECL2 & $\begin{array}{l}\text { In vitro studies; non } \\
\text { autoinmune hyperthyroidism }\end{array}$ & & $(45,142)$ \\
\hline V597F & TM5 & Thytoxicosis and hyperthyroidism & & $(143)$ \\
\hline$\Delta 613-621$ & IC3 & Toxic thyroid nodules & critical for $\mathrm{G}$ protein interaction & (144) \\
\hline T620I & IC3 & FTC & & (145) \\
\hline A623I & IC3 (S+GL) & $\begin{array}{l}\text { increased cell proliferation } \\
\text { TSH independent }\end{array}$ & & (146) \\
\hline M626I & TM6 (S+GL) & Non autoimmune Hyperthyroidism & increased basal cAMP production & (44) \\
\hline I630M & TM6 (6) & Hyperfunctioning thyroid nodules & & (147) \\
\hline F631V & TM6 (S+GL) & Hyperfunctioning thyroid nodules & Constitutive activation of $\mathrm{Ga} / \mathrm{cAMP}$ & (148) \\
\hline F631S & TM6 & non autoinmune hyperthyroidism & & (149) \\
\hline F631I & TM6 & Toxic FTC & & (150) \\
\hline D633Y & TM6 & Toxic FTC & & \\
\hline
\end{tabular}


contains 7 transmembrane (TM) domains anchored to the basolateral plasma membrane of the thyrocytes and a number of other cells. The TSHR promoter contains functional binding sites for several transcription factors including GABP (23), TTFl (24), TR/RXR (25), CREB and ICER (26), nevertheless there is little fluctuation in the TSHR mRNA levels and regulation of functional TSHR is mainly exerted at the postranslational level (27), specially by glycosylation and correct folding at the ER (28).

The mature TSHR is encoded by a single gene with 10 exons $(29,30)$. The protein contains 2 subunits: a large ectodomain also called A or $\alpha$ subunit is encoded by exons 1-8 and binds TSH; a short transmembrane and intracellular domain encoded by exons 9-10 called B or $\beta$ subunit that will interact with G proteins to initiate signalling. Postranslational intramolecular cleavage of a 50 aa chain in the ectodomain close to the membrane and reduction of disulphide bridges releases the A and B subunits (29) followed by shedding of the A subunit from the membrane bound receptor $(31,32)$. The presence of the TSHR ectodomain inhibits an otherwise constitutively active $\beta$ subunit (33) and the interactions between the ectodomain $(\alpha)$, the extracellular loops and transmembrane domain TM6 (in the $\beta$ subunit) are critical for the maintenance of an inactive state (34). Figure 3 recapitulates the main features in the structure of TSHR. The white dotted line overlapping TM5 and
TM6 marks the position of the most frequently found mutations in adenomas. The ectodomain consists mainly of 9 leucine rich repeats (LRR) with interconnecting loops important for receptor structure and activation (35). Precise delineation of the TSH binding pocket of the receptor has been made through deletion-mutation analysis and a panel of antibodies $(36,37)$. The $\beta$ subunit contains the 7 TM domains joined by extracellular loops (ECL) and intracellular loops (ICL), and interacts selectively with $\mathrm{G}$ proteins when the TSHR is activated $(34,38)$. Unstimulated TSHRs form oligomers that return to the monomer state with TSH $(39,40)$. TSHR oligomerisation is an early posttranslational event detectable by FRET (fluorescent resonance energy transfer) in the ER-Golgi (41). After TSH binding, a constitutively oligomeric TSHR dissociates into active monomers, which will be subsequently recruited to the lipid rafts to interact with $\mathrm{G}$ proteins $(42,43)$. Systematic mutagenesis of the $\beta$-subunit has been used to identify critical residues and mechanisms of interactions as illustrated by the following examples. A repulsive separation between TM6 and TM3 in the context of a constitutively active TSHR mutant indicated the opening of the cytoplasmic face of TSHR for G protein coupling (44); mutations in ECL2 and TM6 residues revealed dynamic interactions able to increase or decrease basal TSHR activity (45); deletions and substitutions at the N-terminus of ICL2 served to study TSHR coupling to

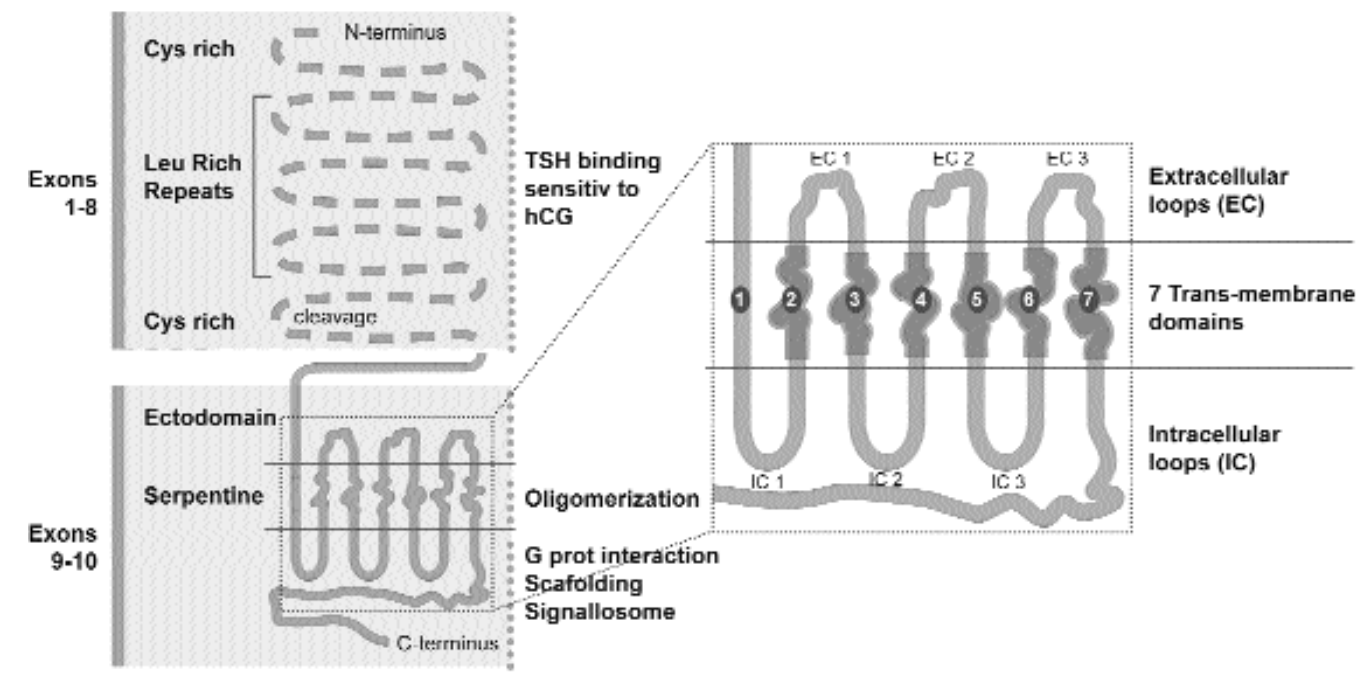

Figure 3. Structure of the TSHR protein: The ectodomain (N-terminus) appears outside the membrane and the serpentine domain through the membrane. On the left the exons coding different regions are denoted. The dashed folded line represents the molecule shedded after the cleavage. Structural domains are highlighted: Cys rich regions and Leucine Rich Repeats. To the right of this scheme the functional significance of each domain is ascribed, (hCG) denotes Corionic Gonadotropin because TSHR may also bind it.The serpentine (C-terminus) is amplified at the right highlighting the 7 transmembrane domains denoted as a number in a circle, the intra cellular loops (ICLs), important for G protein coupling, and the extracellular loops (ECLs), important for basal and activated function. White dots encompassing the 5th-6th transmembrane domains and the 3rd ECL represent the area of the TSHR where most of the activating mutations related to thyroid cancer are described. 
both $\mathrm{G}_{\alpha}$ and $\mathrm{G}_{\mathrm{q}}$ and to demonstrate that ICL2-ICL3 interactions are critical for selective $\mathrm{G}_{\mathrm{q}}$ activation (34). Upon TSH binding, cytoplasmic proteins such as $\beta$-arrestins bind and desensitize GPCRs uncoupling them from $G$ proteins and promoting their internalization. TSHR binds $\beta$-arrestin 2 but does not colocalize with $\beta$-arrestins in endosomes (46). $\beta$-arrestins effects are pleiotropic and have been shown to act also in signal transduction and in transcription. $\beta$-arrestins scaffold some activated GPCRs with the Raf/MAPK/ ERK cascade inhibiting nuclear translocation of ERK (47) and some $\beta$-arrestins translocate to the nucleus and associate with transcription cofactors such as p300 and CBP at the promoters of genes targeted by the transcription factor CREB (cAMP-Response Element Binding Protein) (48). After desensitizing, TSHR is rapidly internalised by clathrin-coated pits $(49,50)$. Most endocytosed receptors recycle back to the membrane, a vital process to maintain the levels. An adaptor protein, hScrib, is crucial to maintain the correct number of TSHR molecules and to scaffold a correct signalling complex. hScrib interacts with TSHR at the cytoplasmic end of the basolateral membrane of the thyrocyte inhibiting basal TSHR internalization. Upon internalisation, hScrib interaction with the internalised TSHR promotes its recycling. To fulfil this function, hScrib interacts with the C-terminus of the TSHR and recruits several enzymatic activities including GTPase activating proteins and Guanine nucleotide exchange factor (GEF) in a complex required for receptor recycling (51). Finally we must mention here a phenomenon termed "specificity crossover" that consist in the binding and activation of TSHR not only by TSH but also by closely related hormones such as luteinizing $(\mathrm{LH})$ and corionic gonadotropin (hCG) $(52,53)$, a phenomenon that may become important in pathologies that curse with excessive hCG secretion. Indeed variants of hCG with increased TSHR affinity have been described in some patients (54).

\section{THE CLASSICAL PATHWAY AND THE NETWORK THAT FRAMES TSH ACTION IN THE THYROCYTE}

Thyrocyte growth occurs mainly through the TSHR mediated increase in cAMP. cAMP-dependent protein kinase (PKA) activation will follow as described below:

1. TSH stimulated TSHR dissociates the heterotrimeric $G$ protein activating the $G_{\alpha s}$ subunit.

2. $G_{\alpha s}$-dependent activation of adenilyl cyclase (AC) follows, increasing cAMP production.
3. cAMP-dependent activates PKA by dissociation of its regulatory subunits.

4. Activated PKA phosphorylates target proteins including membrane receptors, signalling molecules and transcription factors changing their activities to promote growth and differentiation. The variety of targets will further amplify and diversify the final outcome of this pathway. Perhaps the most classical target for PKA after translocation of its catalytic subunit to the nucleus is the transcription factor CREB, whose transcriptional activity will be promoted upon phosphorylation by PKA.

Every intermediary in the pathway described may additionally interact with side molecules belonging to other pathways. This will build up a network responsible for refining every response according to a contextual environment. Altered wiring of this network interconnecting TSHR/PKA with other proliferation pathways such as PI3K, BRaf/MAPK or Wnt plays a pivotal role in cancer, and common targets such as CREB or cyclin Dl may need the integrity of the network to be accurately regulated. We will describe next the classical pathway outlining possible important side branches for thyroid cancer, but since it is out of the scope of this review to analyse them in detail, excellent reviews on each pathway can be consulted elsewhere. Figure 4 outlines the main effectors of TSHR and interactions with other signalling pathways.

\section{STEP 1: The TSHR stimulated by TSH interacts with heterotrimeric $G$ proteins}

TSH induced dissociation of heterotrimeric $\mathrm{G}$ proteins leads to $G_{\alpha}$ and $G_{\beta \gamma}$ activation. There are many subtypes of $\alpha$ and $\beta \gamma$ subunits, each combination activating a different set of pathways, and there are excellent reviews on the subject [i.e.: (55)].

\section{$G_{\alpha}$ proteins}

Photoaffinity labelling of the TSHR followed by inmunoprecipitation suggests that TSHR interacts with all four $G_{\alpha}$ subtypes $\left(G_{\alpha s(L)}, G_{\alpha s(S)}, G_{\alpha q}, G_{\alpha 11}\right.$, $\mathrm{G}_{\mathrm{il}-3}, \mathrm{G}_{0}$ and $\mathrm{G}_{12}$ ) (56), however TSHR signalling in the thyrocyte is mainly mediated by $\mathrm{G}_{\mathrm{\alpha s}}$ and $\mathrm{G}_{\mathrm{\alpha q}}$ coupling to increased cAMP production and phosphoinositide turnover respectively. $G_{\alpha s}$ stimulation of AC will increase cAMP, whose major effector is PKA. This path is further analysed below and activating mutations of the TSHR and $G_{\alpha s}$ that increase AC activity have been identified in hyperfunctioning benign follicular adenomas and less commonly in hypofunctioning adenomas and carcinomas of the thyroid. $G_{\alpha} q / 11$ coupling to TSHR in rat FRTL-5 and human thyrocytes 


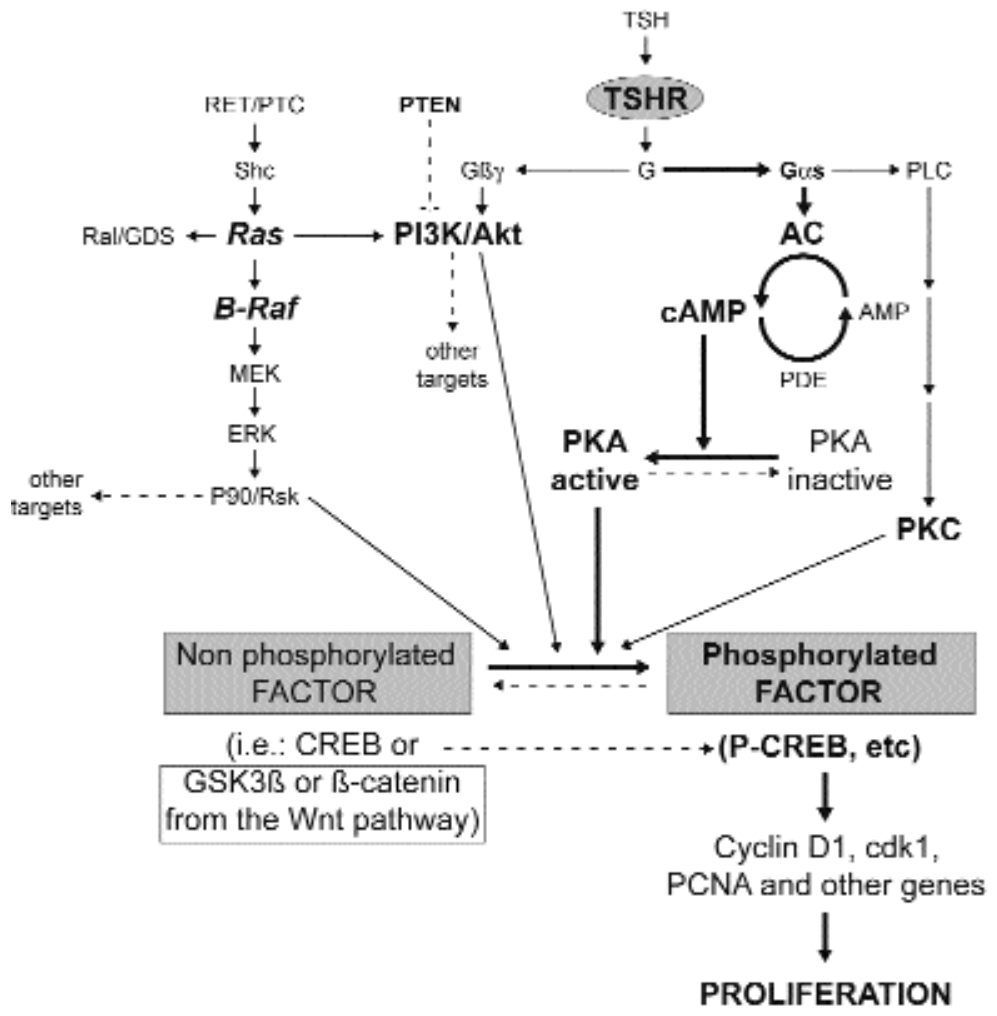

Figure 4. Classical TSHR signalling pathway and the framing network in thyrocyte proliferation. The bold arrows represent the classical TSHR signalling pathway towards proliferation. Normal arrows integrate crosstalking molecules from other signalling pathways. Dashed lines represent other targets that may or may not be related to this pathway. Commonly altered molecules in thyroid cancer that may alter the integrity of the signalling network are enclosed in a square. Examples of integration between the classical TSHR/PKA and the MAPK/ERK, PI3K/Akt and Wnt/ $\beta$-catenin pathways are provided.

stimulates phospholipase C (PLC $\beta)(57,58)$, which catalyses hydrolysis of phosphatidil inositols in the membrane yielding di-acyl-glycerol (DAG) and inositol tri phosphate (IP3) as second messengers. DAG directly stimulates PKC. IP3 increase cytosolic $\mathrm{Ca}^{+2}$ levels (59), which act through a number of effectors including PKC. PKC stimulation is important in thyroid cancer because it is the major effector of tumor promoters such as phorbol esters, and its activation leads to proliferation and de-differentiation in FRTL5 and PC CL3 thyrocytes $(60,61)$. TSHR mediated activation of the PLC-Ca ${ }^{+2}$ cascade has been controversial because it requires very high TSH concentrations in human primary thyrocytes and in FRTL- 5 cells (62-64), however, TSHR clearly increases $\mathrm{Ca}^{+2}$ mobilizations at least in certain contexts such as repeated stimulation or simultaneous activation of other GPCRs (65). Increases in PLC-PKC activities have been reported in thyroid carcinomas (66) but it could be due to activation of other receptors because TSHR is poorly expressed in neoplastic tissue (67); moreover, there is a negative feed back from PKC to PLC $\beta$ in thyroid carcinomas (68), and constitutively active mutants of $\mathrm{G}_{\alpha \mathrm{q}}$ have never been found in thyroid neoplasms (69), although the mutation induces thyroid hyperplasia in mice. Hence, the significance of the TSHR-G $\mathrm{G}_{\alpha \mathrm{q}}$-PLC-PKC in thyroid cancer still remains obscure. Different $\mathrm{G}$ proteins compete for binding of the TSHR (70) mainly $G_{\alpha s}$ or $\mathrm{G}_{\alpha q}$ in thyrocytes which activate the PKA or PKC pathways respectively. Functional interference between the cAMP/PKA and PKC pathways has been described in normal thyrocytes $(71,72)$ and in hyperfunctioning thyroid adenoma bearing $G_{\alpha s}$ mutants that induce the cAMP cascade and suppress the PLC-Ca ${ }^{2+}$ signalling (73). Transgenic mice expressing $G_{\alpha}$ mutants that constitutively activate both AC and PLC suggest that these cascades may cooperate in vivo towards development of thyroid follicular malignancies (74).

Finally, TSHR may also couple to $G \alpha_{i 1-3}$, which will inhibit AC and decrease cAMP levels providing a mechanism to desensitise the TSHR. 


\section{$G_{\beta \gamma}$ activation}

GPCR activated $G_{\beta \gamma}$ dimers may induce the MAPK and PI3K signalling pathways, which are involved in processes important for tumorigenesis such as proliferation and cytoskeletal remodelling. The diversity of $\mathrm{G}_{\beta \gamma}$ subunits would allow at least 60 possible combinations, but the composition of the $\mathrm{G}_{\beta \gamma}$ dimers in thyrocytes has not been examined in that detail. More than 20 effectors have been reported for $\mathrm{G}_{\beta \gamma}$ activation including phospholipases (75), ACs (76), other GPCRs and PI3Ks (77). In the thyrocyte, $\mathrm{G}_{\beta \gamma}$ directly activates PLC $\beta$ and PKC, which activates the PKB/Akt pathway. Our lab has shown that TSHR mediated $\mathrm{G}_{\beta \gamma}$ activation directly stimulates PI3K in rat thyrocytes leading to diminished NIS expression (Zaballos, MA et al. 2007 submitted).

In summary, TSHR coupling to G proteins provides the opportunity for activation of the PKA, PKC and PI3K pathways, but mutations in G proteins hardly correlate with thyroid cancers, and hot thyroid nodules with constitutively active TSHR mutants very often bear reduced $G_{\alpha}$ protein expression presumably as a mechanism of desensitizing the TSHR (78).

\section{STEP 2: TSHR-dependent activation of $\mathbf{G}_{\alpha s}$ stimulates the AC increasing CAMP levels}

cAMP has cell type specific effects and the outcome on proliferation is largely attributed to cross talk with the Ras-Raf-MAPK-ERK pathway. Besides PKA, a number of cAMP effectors may cross talk with the MAPK pathway in the thyrocyte mainly GTP-exchange factors (GEFs or Epac). Finally, other cAMP effectors in the thyrocyte include cAMP-gated membrane ion channels (79), and some phosphodiesterases (PDEs) such as PDE4. Steady state cAMP levels result from production by AC and degradation by PDEs. cAMPPKA-dependent PDE4 activation feeds back negatively providing a mechanism to stop the signal (80). Given the enormous variety of cAMP effectors, our understanding of this very complex pathway is far from complete.

cAMP-dependent PKA activation by binding to its regulatory subunits is analysed in "Step 3" and here we briefly discuss other cAMP effectors. Although PKA activation in thyroid cells is necessary for cAMP mitogenic effects (15), it is not sufficient (81). In fact, cAMP inhibits growth in some human thyroid tumoral cell lines $(82,83)$ perhaps involving negative feed back mechanisms such as over expression of PDE4, as described for autonomous hyperfunctioning thyroid nodules bearing constitutive activation of the cAMP pathway (84). In autonomous hyperplasic thyroid ade- nomas with constitutive activation of the cAMP pathway by TSHR and $\mathrm{G}_{\alpha \mathrm{s}}$ mutants is not sufficient to generate toxic thyroid adenomas (85). Cooperation with other signalling pathways initiated by insulin/IGF-1, bFGF, EGF or serum factors $(14,15)$ is required by TSH in thyrocytes to display full mitogenic activity. Other cAMP effectors include GEF or Epac, which activate the small GTPases Rapl, Rap2 and Ras, providing another mechanism for diversification and tuning of the signal. The thyrocyte is highly enriched in Epacs (86-88). GTP bound Rapl may activate Raf-1, B-Raf or C-Raf leading to activation of MAPK/ $E R K 1 / 2$ or $p 38 M A P K$ and mitogenesis; Rapl is over expressed in thyroid follicular cancer (89), and mutations in its effector B-Raf are present in most PTC. Activated Ras signalling may lead to $M A P K$ or to $P I 3 K / P D K I$ activation, both pathways being involved in mitogenesis. Ras is required for cAMP dependent mitogenesis in several rat thyroid cell lines such as FRTL-5 and WRT $(90,91)$ and in $60-70 \%$ follicular thyroid adenomas, and carcinomas components of the RET/Ras/B-RAF signalling pathway are mutated (92-96). The role of this pathway is further discussed under the epigraph "Networking the TSHR" and has been widely reviewed elsewhere.

\section{STEP 3: CAMP-dependent activation of PKA}

PKA is composed of 2 catalytic and 2 regulatory subunits that bind cAMP. To date at least 3 different catalytic and 4 regulatory subunits have been found and depending on the combination the corresponding PKA molecules will be targeted to cytosolic substrates (PKA I) or to the membrane of certain organelles (PKA II) via a family of proteins called A kinase anchoring proteins or AKAPs (97). Selective activation of the cytosolic or membrane anchored forms of PKA in the thyrocyte has demonstrated specialised functions. PKA I stimulation increased iodide uptake in FRTL5 cells without affecting gene transcription while selective PKA II activation induced gene transcription and proliferation in FRTL5 cells (98).

Mutations that activate the catalytic subunits or inactivate the regulatory subunits would lead to the constitutive PKA activity found in endocrine tumors but so far no mutants for the catalytic subunits have been correlated to endocrine tumors. Inactivating mutations in the regulatory subunit RI leading to PKA I stimulation has been related to benign endocrine neoplasms, functioning nodules and follicular carcinomas of patients with Carney complex (99). However, selective PKA I activation by cAMP analogs showed anti proliferative activity in BRAF-mutated cells. PKA 
II appears to be more clearly involved: silencing its regulatory subunit RII $\beta$ impairs TSH nuclear effects, and loss of RII $\beta$ expression in three human cancer cell lines suggests an essential role for PKA II in TSHRmediated proliferation (98).

The transcription factor CREB is the classical nuclear target of PKA, although it is also targeted by other pathways, and PKA also targets other nuclear factors as we will see below.

\section{STEP 4: PKA dependent activation of the transcription factor CREB}

The ubiquitous transcription factor CREB binds to cAMP response elements and upon activation stimulates transcription at selected promoters (88). Transcription factors from the CREB/CREM family are required for CAMP-dependent proliferation in dog thyroid primary cultures and are tightly regulated by TSH and other factors (26). CREB activity has been shown to be important for TSH dependent thyrocyte proliferation in vitro and in vivo although it is not sufficient to mimic TSH-dependent DNA synthesis. In vitro, the importance of CREB was tested by stable transfection of FRTL- 5 cells with either wild type CREB, which did not affect growth, or a dominant negative version dnCREB, which reduced up to $40 \%$ TSH-induced growth of the thyrocytes (100). In vivo, transgenic mice with targeted expression of dnCREB to their thyroid glands exhibited severe growth retardation and primary hypothyroidism; dnCREB inhibited the expression of the genes for Pax8, TTF-1, and TTF-2, which are required for the expression of TSHR, thyroglobulin and thyroperoxidase (101). Alterations of CREB family members can be observed in endocrine tumors (102), and levels of total CREB are markedly reduced in thyroid carcinomas (103), but their role in thyroid cancer remains highly controversial. Contradictory results have been reported in hyperfunctioning thyroid adenomas: some laboratories find a reduction of P-CREB (Ser 133) (104) while others do not find differences between nodular and extranodular tissue (103). Perhaps the interpretation of these results is too simplistic having in mind the multiple modifications that would affect CREB activity. It is generally believed that recruitment of the coactivators CREB-binding protein (CBP) and p300 after signal induced phosphorylation of CREB at Ser 133 strongly enhances its transcriptional activity. However, a number of kinases may phosphorylate CREB in Ser 133 including PKA, $\mathrm{PKB} /$ Akt, PKC, Rskl/2. CREB activation can also be promoted by Ser 133 independent mechanisms and not all the signals that induce Ser 133 phosphorylation of CREB enhance its transcriptional activity. Furthermore, CREB is subjected to other phosphorylations, de-phosphorylations (by PP2A and PP1), acetylation by CBP, ubiquitylation and SUMOylation and, depending on its modifications, CREB interacts with other proteins that may perturb its localisation and/or turnover leading to activity changes [reviewed in $(105,106)]$. Thus CREB acts as a platform targeted by multiple signalling pathways where interference or integration takes place to render a gene expression profile extraordinarily tuned to incoming signals. CREB may use coactivators that are effectors of other signalling pathways (i.e. the Wnt effector $\beta$-catenin) and targets a number of genes involved in diverse aspects of proliferation, for example cyclin Dl, which is also targeted by the Wnt signalling pathway and others. This provides new opportunities for integration. A complete genome wide analysis of CREB target genes has recently been published (107). Furthermore, other transcription (co)factors involved in proliferation such as $\beta$-catenin and others are also activated by PKA.

\section{TSHR ALTERATIONS RELATED TO THYROID CANCER}

Excesses or defaults in TSHR activity may play a role in thyroid disease and cancer. Both can be achieved by a number of mechanisms including: improper epigenetic marking of the gene, incorrect transcriptional regulation or mutations in critical domains.

\section{Altered levels of TSHR expression}

Lack or low TSHR expression correlates with aberrant methylation of the promoter in human thyroid carcinomas and in thyroid cancer cell lines (108). The silencing mechanism may also include the binding of the methylation-sensitive GABP transcription factor (23). TSHR function is required for NIS expression and iodide uptake. Low or absent TSHR expression and lack of NIS expression correlates with thyroid carcinomas of the worse prognostic that cannot be eliminated with radioactive iodide (109). Excessive TSHR expression does not correlate with malignant thyroid cancer to our knowledge, although a number of constitutively activating mutations have been described in thyroid adenomas as we describe below.

\section{Mutations also change the levels of functional TSHR}

Mutations may lead to altered location, turnover or recycling, activation/deactivation, postranslational 
modifications or protein-protein interactions, including influences by and on other GPCRs, scaffolding, signaling mediators, desensitation, etc. TSHR activity is mainly controlled through protein-protein interactions and constitutively active mutants correlate with thyroid adenomas and nodules, while inactivating mutations correlate with diverse forms of hypothyroidism.

\section{Inactivating mutations}

More than 25 distinct loss-of-function mutations in the TSHR gene have been reported $(41,110)$, including those occurring at the germ line and causing congenital hypothyroidism. So far none of these mutations appear to be related to the onset of thyroid cancer. Inactive TSHR fails to induce thyroid cell proliferation and is unlikely to induce nodule formation. Reduced TSHR expression in thyroid cancers may be secondary to ongoing de-differentiation, may happen in parallel or may cause disappearance of other differentiation markers.

\section{The TSHR gene is highly susceptible to constitu-} tively activating mutations

Structural studies discarded TSHR as a candidate oncogene for thyroid tumor (111), however G protein coupling is a critical step and most gain of function mutations are located in exons 9 and 10 corresponding to TM domains (112,113), ICLs or ECLs (114,115). Not surprisingly, these sites are critical for $\mathrm{G}$ protein coupling (see figure 3). A list of TSHR mutants may be found at <http://www.uni-leipzig.de/innere/tshr> and we have updated it in table 1 . Spontaneous activating mutations of the TSHR gene appear at the onset of autonomous functioning thyroid adenomas $(116,117)$ and more rarely of thyroid carcinomas (118-124). Somatic mutations cause autonomous nodules and germ-line mutations cause congenital hyperthyroidism and hereditary non-autoimmune toxic thyroid hyperplasia. Patients with activating TSHR mutations suffer hyperthyroidism; the disease activity directly correlates with the degree of TSHR activation measured as basal cAMP production (125). Likewise, thyroid nodules and goitre develop earlier in patients carrying TSHR variants with high constitutive receptor (126-130) [reviewed by (131)]. Furthermore, in multinodular goiters different TSHR activating mutations have been found in separate hot nodules of the same gland suggesting a role in true nodule formation (112). Constitutively activating mutations lie also at the root of toxic thyroid adenomas and differentiated thyroid carcinomas (120). Meanwhile, $\mathrm{G}_{\alpha \mathrm{s}}$ mutations are very infrequent in hyperthyroidism or toxic adenomas, suggesting that this subunit does not play an important role, a question intensely debated $(132,133)$. Some authors have compared the characteristics and location of the most frequently appearing germ-line and somatic mutations in the TSHR gene. Germ-line mutations are mostly transitions and affect residues $[183,505,509$, and 597] never involved in somatic mutations. Somatic mutations are usually transversions and affect residues 630 and 633 never affected by germ-line mutations. Finally, several residues located in a mutation cluster region [619-639] at TM6 are affected by both somatic and germinal mutations (134).

Thus, the question of whether or not TSHR mutations are involved in the onset of thyroid cancers remains controversial as explained in previous sections. Interpretations are complicated by the fact that biological effects of activating TSHR mutations vary with the ambient iodide supply. In regions of iodine deficiency, higher incidence of toxic adenoma and toxic multi-nodular goitre has been reported, where $50-80 \%$ of these toxic adenomas are caused by TSHR mutations (135).

\section{Postranslational modifications and protein interactions}

Immunoelectron microscopy studies show that in human thyrocytes most of the TSHR is glycosilated and palmytoylated and is present on the cell surface. Other modifications such as acetylation, methylation, sumoylation, ubiquitination, etc. have not been reported, but interactions with several proteins that may scaffold its signalling or recycle back the endocytosed TSHR are important for its functionality. These TSHR interacting proteins include fibronectin, calreticulin, calnexin, $\beta$ arrestin, Scrib, HSP5, JAKl /2, Stat3, and other GPCRs such as the LHR. Mutations or altered expression in these protein effectors may give a phenotype related to thyroid cancer. For example, over expression of $\beta$ arrestin 2 has been found in thyroid toxic nodules (155). TSHR interacting proteins open new possibilities for networking the signals from the TSHR that will have to be explored. Besides the previously mentioned proteins other related hormones, such as hCG, or antibodies from autoinmune diseases, such as Graves' disease, may also interact with the TSHR and be involved in thyroid cancers. Anti-TSHR antibodies binding to the TSHR in thyroid nodules might promote growth via direct and indirect mechanisms such as upregulating the expression of insulin receptors (156), which may transduce IGF-II growth effects (157). Anti-TSHR antibodies also stimulate angiogenesis upregulating VEGF and its receptor (flt) in thyroid cells (158). Thus, high levels of antiTSHR antibodies in Graves' patients might stimulate thyroid cancer growth and early metastatic spread [an issue that is discussed in (159)]. 


\section{NETWORKING THE TSH RECEPTOR SIGNALLING IN THYROID CANCER}

Cancer arises from accumulation of mutations in important genes or oncogenes. Most known oncogenes are keysignalling molecules important for the integrity of the signalling networks that maintain cell homeostasis. Oncogenes relevant to thyroid carcinogenesis are normally engaged in proliferation and/or survival pathways, the paradigms are RET/Ras/B-Raf, PTEN/Akt and Ecadherin/ $\beta$-catenin representing the MAPK, PI3K and Wnt pathways respectively. These pathways are integrated in the thyrocyte signalling network among them and with the cAMP/PKA pathway and altering their crosstalk may lead to carcinogenesis.

\section{The MAPK pathway and its cross talk with TSHR/cAMP/PKA}

The MAPK pathway in the thyrocyte conveys proliferation signals from tyrosine kinase receptors such as RET. Hyperactivating RET mutations in the kinase domain define MTCs and rearrangements (RET/ PTCs) are frequent at early onset of PTCs; RET mutants signal through B-Raf to activate the MAPK pathway in thyroid cells (160), and B-Raf mutations (V600E) are present in more than $40 \%$ of PTCs $(161,162)$. The significance of the RET/Ras/BRaf/ ERK pathway in thyroid carcinogenesis has been widely reviewed (163). Crosstalk between the Ras/ MAPK/ERK and the cAMP/PKA pathways has long been recognised and cAMP may either suppress or induce the MAPK pathway depending on the cell type (164). RET/PTC2 is a particularly interesting rearrangement cross-linking the MAPK and PKA pathways because the kinase domain of RET is fused to the regulatory subunit of PKA II (165). In FRTL-5 rat thyrocytes, both TSH and cAMP induce ERK (166), and these cells require Ras for TSH-stimulated mitogenesis $(90,91)$; in dog and human thyrocytes, indirect evidence suggest the same because a MEK inhibitor blocks TSH stimulated DNA synthesis (167). cAMP may activate B-Raf and ERK through PKA-dependent or independent mechanisms that need further clarification at the thyrocyte. Thus, in thyroid cells cAMP does not inhibit MAPK signalling but whether it activates it or not remains controversial due to differences among distinct in vitro systems (15). The high sensitivity to BRaf mutations exhibited by thyrocytes in cancer is intriguing and remarkable and perhaps is exacerbated by the lack of cAMP-dependent mechanisms to suppress B-Raf/ERK activity.

\section{The PI3K/AKT pathway and its crosstalk with TSHR/CAMP/PKA}

$\mathrm{PI} 3 \mathrm{~K} / \mathrm{AKT}$ is a pleiotropic kinase downstream of many growth factor receptors involved in cell survival, proliferation and cancer. Indirect evidence of the role of PI3K in thyroid cancer comes from the use of an Akt inhibitor (KP372-1) that suppresses proliferation and induces apoptosis in thyroid cancer cells (168). Activating mutations of Akt or silencing its upstream suppressor PTEN (Phosphatase and TENsin homolog) is frequently associated with thyroid carcinoma (169). PTEN is a dual specificity phosphatase mutated or silenced in the majority of human advanced cancers. Also in thyroid cancers has been found loss, reduction, or inappropriate subcellular compartmentalization of PTEN (170,171). A rearrangement with the histone $\mathrm{H} 4$ gene has been found in irradiated thyroid cell lines, H4/PTEN (172). PTEN silencing has been suggested to be involved in the carcinogenesis of highly malignant or late-stage thyroid cancers $(170,173)$, and reintroduction of PTEN in thyroid cancer cell lines causes Gl arrest in the differentiated and apoptosis in the most undifferentiated thyroid cancer cell lines (174). TSHR immunoprecipitates exhibit PI3K activity, which is greater after TSH treatment. Concomitantly, the kinase PDKl is redistributed from the cytoplasm to the plasma membrane in a PI3Kand PKA-dependent manner after TSH treatment (175). The regulatory subunit of PI3K, p85 phosphorylated at Ser 83 , binds the regulatory subunit of PKA, RII $\beta$ and mediate TSH-cAMP-PKA growth and survival signals (176). Moreover, the PI3K/Akt pathway has been suggested to be activated in thyroid tumors by RET oncoproteins that associate with $\mathrm{RAI}$ (ShcC/N-Shc) and recruit GAB 1 (Grb 2-associated binder 1) (177). Additionally, PI3K is involved in IGF-1 or insulin mediated cooperation with TSH for DNA synthesis in thyrocytes. The interactions between the Ras/Raf/MEK/ERK and Ras/PI3K/PTEN/Akt pathways are crucial to regulate growth and may be altered in tumorigenesis.

\section{The Wnt pathway}

The Wnt pathway plays a pivotal role in development and in epithelial renewal and components such as $\beta$ catenin, APC and E-cadherin are often mutated in thyroid cancer $(178,179)$. $\beta$-catenin mutations are more frequent in undifferentiated cancers or ATCs $(180,181)$, and abnormalities of the E-cadherin/ catenin complex (methylation of the promoter and silencing or mutations) are associated with the more aggressive behaviour of certain PTCs (182). The Wnt components E-cadherin and $\beta$-catenin may crosstalk with the classical TSH/cAMP/CREB pathway to con- 
trol thyrocyte proliferation. PKA is known to potentiate Wnt signalling in some cells stabilizing $\beta$-catenin and inhibiting GSK3 $\beta(183,184)$. The CREB transcription factor might be targeted by both PKA and Wnt signalling, and recently its role in lithium-stimulated thyrocyte proliferation has been challenged (185). Although these authors conclude that CREB does not play a role in lithium-induced thyroid proliferation, their experiments do not rule out a possible role of CREB in Wnt-dependent proliferation of thyrocytes. Some components of the Wnt pathway (GSK3 $\beta$ ) are also targeted by PI3K. Cyclin Dl is a transcriptional target for both CREB and $\beta$-catenin and is over expressed in thyroid papillary microcarcinoma with aberrant $\beta$-catenin (186).

In summary, mutations of individual components may cause fundamental functional changes well beyond the pathway they function in, due to the crosstalk between signalling pathways. One of the molecules most mutated in cancer in general and in ATC also is p53, another common target for many signalling pathways including PI3K, cAMP, and ERK. p53 is inactivated in $50 \%$ of human cancers and $14 \%$ of malignant thyroid tumors; p53 mutations appear "late" in thyroid carcinogenesis and are associated with loss of differentiation and transformation to the anaplastic phenotype (132). p53 is a transcription factor and plays multiple regulatory functions in the cell cycle, DNA repair, and apoptosis. Reintroduction of wild type p53 in thyroid tumoral cell lines arrests growth and/or induces apoptosis $(21,187)$. p53 protein levels may be increased by cAMP, ERK, and also through the activation of PTEN, and recently a differential proteomic approach has identified several targeted proteins for mutant $\mathrm{p} 53$ associated with thyroid cell transformation (188). The TSHR and p53 connection in thyrocytes still has to be clarified but it is remarkable that stable expression of a p53 mutant which does not bind DNA (VI43A), induces loss of differentiation markers and TSH-independent growth in PC CL3 thyrocytes. In contrast, a p53 mutant (S392A), which does not interfere with DNA binding, causes only loss of TSH dependency for growth (188).

\section{FUTURE PERSPECTIVES}

Undifferentiated thyroid cancers are among the most rapid life-threatening and are characterised by abnormal $\mathrm{CpG}$ islands methylation patterns in critical promoters. Silencing of TSHR, PTEN and p53 appears to be related to the most aggressive behaviour of thyroid cancer, and reintroduction of each of these genes in human thyroid cancer cell lines either restores differentiation or arrest cell cycle or causes apoptosis. Hypomethylation of heterochromatin has been correlated with tumour progression in thyroid cancer specimens (189), and hypermethylation of tumor supressor promoters appears in undifferentiated thyroid cancer causing failure in clinical radioiodine treatment $(171,173)$. Thus, aberrant DNA methylation patterns are some of the epigenetic marking processes more likely involved in the onset of thyroid cancer. Demethylating agents or inhibitors of the DNA methylase may be promising hopes in the treatment of the worse thyroid cancers, but their clinical value remains to be investigated and they have to be specifically targeted. In general, the development of molecular-based therapies for thyroid carcinoma patients resistant to standard radioiodine treatment such as histone deacetylase inhibitors combined with retinoids or the use of specific targeted RNAis for invasion/metastasis molecules represent a critical issue and an exciting field in new drug development in thyroid cancer.

Large chromatin alterations related to thyroid cancer, such as the chromosomal rearrangements: RET/PTCs or Pax8/PPAR $\gamma$ chimeras (190), coincide in their activation of the Ras/Raf/MEK/ERK pathway, which is also induced by TSHR signalling in the thyrocyte. Chromatin alterations related to cancer, especially epigenetic modifications, need to be further explored, especially lost of imprinting (LOI) and lost of heterozigosity (LOH) studies will reveal new clues to the onset of cancer.

Finally, an exciting aspect in thyroid cancer research is the definition and biological characterization of the precursor cells that give rise to thyroid carcinomas. Mouse embryonic stem cells might now be differentiated into thyroid follicular cells in vitro (5), and this system will surely help to identify key events in thyroid carcinogenesis and understanding the role of TSHR.

\section{ACKNOWLEDGEMENTS}

We are grateful to grants URJC-CM-2006-BIO-0522 (to CG-J) and BFU 2004-03 169, and FIS PI 041216, PI 042374, RD06 00200060 (to PS) for supporting our work.

\section{REFERENCES}

1. Davies $\mathrm{L}$, Welch $\mathrm{GH}$. Increasing incidence of thyroid cancer in the United States, 1973-2002. JAMA 2006;295:2164-7. 
2. Takano T. Fetal cell carcinogenesis of the thyroid: a hypothesis for better understanding of gene expression profile and genomic alternation in thyroid carcinoma. Endocr $J$ 2004;51:509-15.

3. Takano T. Fetal cell carcinogenesis of the thyroid: Theory and practice. Semin Cancer Biol 2007:17(3):233-40.

4. Takano T, Amino N. Fetal cell carcinogenesis: a new hypothesis for better understanding of thyroid carcinoma. Thyroid 2005; 15:432-8.

5. Arufe MC, Lu M, Kubo A, Keller G, Davies TF, Lin RY. Directed differentiation of mouse embryonic stem cells into thyroid follicular cells. Endocrinology 2006;147:3007-15.

6. Marians RC, Ng L, Blair HC, Unger P, Graves PN, Davies TF. Defining thyrotropin-dependent and -independent steps of thyroid hormone synthesis by using thyrotropin receptor-null mice. Proc Natl Acad Sci U S A 2002:99:15776-81.

7. Postiglione MP, Parlato $R$, Rodriguez-Mallon $A$, Rosica $A$, Mithbaokar P, Maresca M, et al. Role of the thyroid-stimulating hormone receptor signaling in development and differentiation of the thyroid gland. Proc Natl Acad Sci U S A 2002;99:15462-7.

8. Brown SR. Minireview: developmental regulation of thyrotropin receptor gene expression in the fetal and newborn thyroid. Endocrinology 2004;145:4058-61.

9. Felice DM, Postiglione MP, Lauro DR. Minireview: thyrotropin receptor signaling in development and differentiation of the thyroid gland: insights from mouse models and human diseases. Endocrinology 2004;145:4062-7.

10. Takahashi S, Conti M, Wyk VJ. Thyrotropin potentiation of insulin-like growth factor-I dependent deoxribonucleic acid synthesis in FRTL-5 cells: mediation by an autocrine amplification factor(s). Endocrinology 1990;126:736-45.

11. Becks GP, Logan A, Phillips ID, Wang JF, Smith C, DeSousa $D$, et al. Increase of basic fibroblast growth factor (FGF) and FGF receptor messenger RNA during rat thyroid hyperplasia: temporal changes and cellular distribution. J Endocrinol 1994:142:325-38

12. Pietrzik CU, Hoffmann J, Stober K, Chen CY, Bauer C, Otero DA, et al. From differentiation to proliferation: the secretory amyloid precursor protein as a local mediator of growth in thyroid epithelial cells. Proc Natl Acad Sci U S A 1998;95:1770-5.

13. Hoffmann S, Hofbauer LC, Scharrenbach V, Wunderlich A Hassan I, Lingelbach S, et al. Thyrotropin (TSH)-induced production of vascular endothelial growth factor in thyroid cancer cells in vitro: evaluation of TSH signal transduction and of angiogenesis-stimulating growth factors. J Clin Endocrinol Metab 2004;89:6139-45.

14. Medina DL, Suzuki K, Pietrarelli M, Okajima F, Kohn LD, Santisteban $P$. Role of insulin and serum on thyrotropin regulation of thyroid transcription factor- 1 and pax-8 genes expression in FRTL-5 thyroid cells. Thyroid 2000;10:295303.

15. Kimura T, Van Keymeulen A, Golstein J, Fusco A, Dumont JE, Roger PP. Regulation of thyroid cell proliferation by TSH and other factors: a critical evaluation of in vitro models. Endocr Rev 2001;22:631-56.

16. Hoffmann S, Maschuw K, Hassan I, Wunderlich A, Lingelbach $S$, Ramaswamy $A$, et al. Functional thyrotropin receptor attenuates malignant phenotype of follicular thyroid cancer cells. Endocrine 2006;30:129-38.

17. Ohta K, Endo T, Onaya T. The mRNA levels of thyrotropin receptor, thyroglobulin and thyroid peroxidase in neoplastic human thyroid tissues. Biochem Biophys Res Commun 1991;174:1148-53.

18. Chia SY, Milas M, Reddy SK, Siperstein A, Skugor M, Brainard J, et al. TSH receptor mRNA measurement in blood as a marker for circulating thyroid cancer cells and its role in the preoperative diagnosis of thyroid cancer. J Clin Endocrinol Metab 2007;92(2):468-75.

19. Parmentier M, Libert F, Maenhaut C, Lefort A, Gerard C, Perret $\mathrm{J}$, et al. Molecular cloning of the thyrotropin receptor. Science $1989 ; 246: 1620-2$.
20. Libert F, Lefort A, Gerard C, Parmentier M, Perret J, Ludgate $\mathrm{M}$, et al. Cloning, sequencing and expression of the human thyrotropin (TSH) receptor: evidence for binding of autoantibodies. Biochem Biophys Res Commun 1989; $165: 1250-5$.

21. Nagayama Y, Kaufman DK, Seto P, Rapoport B. Molecular cloning, sequence and functional expression of the cDNA for the human thyrotropin receptor. Biochem Biophys Res Commun 1989;165:1184-90.

22. Misrahi M, Loosfelt H, Atger M, Sar S, Guiochon-Mantel A, Milgrom E. Cloning, sequencing and expression of human TSH receptor. Biochem Biophys Res Commun 1990; 166:394-403.

23. Yokomori N, Tawata M, Saito T, Shimura H, Onaya T. Regulation of the rat thyrotropin receptor gene by the methylationsensitive transcription factor GA-binding protein. Mol Endocrinol 1998;12:1241-9.

24. Ohe K, Ikuyama S, Takayanagi R, Kohn LD, Nawata H. Interferon-gamma suppresses thyrotropin receptor promoter activity by reducing thyroid transcription factor-1 (TTF-1) binding to its recognition site. Mol Endocrinol 1996; 10:826-36.

25. Chen TS, Lin DJ, Lin HK. Characterization of a thyroid hormone-mediated short-loop feedback control of TSH receptor gene in an anaplastic human thyroid cancer cell line. $\mathbf{J}$ Endocrinol 2002;175:459-65.

26. Uyttersprot N, Costagliola S, Dumont EJ, Miot F. Requirement for cAMP-response element (CRE) binding protein/CRE modulator transcription factors in thyrotropin-induced proliferation of dog thyroid cells in primary culture. Eur $\mathbf{J}$ Biochem 1999;259:370-8.

27. Seetharamaiah SG, Dallas SJ, Prabhakar SB. Glycosylated ectodomain of the human thyrotropin receptor induces antibodies capable of reacting with multiple blocking antibody epitopes. Autoimmunity 1999;29:21-31.

28. Siffroi PJ, Bourhis LC, Dadoune PJ. Collecting human spermatozoa onto filters for FISH. Application to the study of extreme oligozoospermia. Acta Cytol 2002;46:1123-8.

29. Loosfelt H, Pichon C, Jolivet A, Misrahi M, Caillou B, Jamous $M$, et al. Two-subunit structure of the human thyrotropin receptor. Proc Natl Acad Sci U S A 1992;89:3765-9.

30. Misrahi M, Ghinea N, Sar S, Saunier B, Jolivet A, Loosfelt H, et al. Processing of the precursors of the human thyroid-stimulating hormone receptor in various eukaryotic cells (human thyrocytes, transfected $L$ cells and baculovirus-infected insect cells). Eur J Biochem 1994;222:711-9.

31. Couet J, Sar S, Jolivet A, Hai MT, Milgrom E, Misrahi M. Shedding of human thyrotropin receptor ectodomain. Involvement of a matrix metalloprotease. J Biol Chem 1996;271:4545-52.

32. Tanaka K, Chazenbalk GD, McLachlan SM, Rapoport B. Subunit structure of thyrotropin receptors expressed on the cell surface. J Biol Chem 1999;274:33979-84.

33. Zhang $\mathrm{M}$, Tong KP, Fremont $\mathrm{V}$, Chen $\mathrm{J}$, Narayan $\mathrm{P}$, Puett $\mathrm{D}$, et al. The extracellular domain suppresses constitutive activity of the transmembrane domain of the human TSH receptor: implications for hormone-receptor interaction and antagonist design. Endocrinology 2000;141:3514-7.

34. Neumann S, Krause G, Claus M, Paschke R. Structural determinants for g protein activation and selectivity in the second intracellular loop of the thyrotropin receptor. Endocrinology 2005; $146: 477-85$

35. Costagliola S, Khoo D, Vassart G. Production of bioactive amino-terminal domain of the thyrotropin receptor via insertion in the plasma membrane by a glycosylphosphatidylinositol anchor. FEBS Lett 1998;436:427-33.

36. Jeffreys J, Depraetere H, Sanders J, Oda Y, Evans M, Kiddie A, et al. Characterization of the thyrotropin binding pocket. Thyroid 2002;12:1051-61.

37. Nunez Miguel R, Sanders J, Jeffreys J, Depraetere H, Evans $M$, Richards T, et al. Analysis of the thyrotropin receptor-thyrotropin interaction by comparative modeling. Thyroid 2004; 14:991-1011. 
38. Vlaeminck-Guillem V, Ho SC, Rodien P, Vassart G, Costagliola S. Activation of the cAMP pathway by the TSH receptor involves switching of the ectodomain from a tethered inverse agonist to an agonist. Mol Endocrinol 2002;16:736-46.

39. Graves PN, Vlase H, Bobovnikova Y, Davies TF. Multimeric complex formation by the thyrotropin receptor in solubilized thyroid membranes. Endocrinology 1996;137:3915-20.

40. Latif R, Graves P, Davies FT. Ligand-dependent inhibition of oligomerization at the human thyrotropin receptor. $\mathbf{J}$ Biol Chem 2002;277:45059-67.

41. Calebiro D, de Filippis T, Lucchi S, Covino C, Panigone S, Beck-Peccoz $P$, et al. Intracellular entrapment of wild-type TSH receptor by oligomerization with mutants linked to dominant TSH resistance. Hum Mol Genet 2005;14:2991-3002.

42. Moffett S, Brown AD, Linder EM. Lipid-dependent targeting of $\mathrm{G}$ proteins into rafts. J Biol Chem 2000;275:2191-8.

43. Davies T, Marians R, Latif R. The TSH receptor reveals itself. J Clin Invest 2002;110:161-4.

44. Ringkananont U, Van Durme J, Montanelli L, Ugrasbul F, Yu YM, Weiss RE, et al. Repulsive separation of the cytoplasmic ends of transmembrane helices 3 and 6 is linked to receptor activation in a novel thyrotropin receptor mutant (M626I). Mol Endocrinol 2006;20:893-903.

45. Kleinau G, Brehm M, Wiedemann U, Labudde D, Leser U, Krause G. Implications for molecular mechanisms of glycoprotein hormone receptors using a new sequence-structurefunction analysis resource. Mol Endocrinol 2007;21:574-80.

46. Frenzel R, Voigt C, Paschke R. The human thyrotropin receptor is predominantly internalized by beta-arrestin 2 . Endocrinology 2006;147:3114-22.

47. Caunt CJ, Finch AR, Sedgley KR, Oakley L, Luttrell LM, McArdle CA. Arrestin-mediated ERK activation by gonadotropinreleasing hormone receptors: receptor-specific activation mechanisms and compartmentalization. J Biol Chem 2006;281:2701-10.

48. Ma L, Pei G. $\beta$-arrestin signaling and regulation of transcription. J Cell Sci 2007;120:213-8.

49. Baratti-Elbaz C, Ghinea N, Lahuna O, Loosfelt H, Pichon C, Milgrom E. Internalization and recycling pathways of the thyrotropin receptor. Mol Endocrinol 1999;13:1751-65.

50. Singh PS, McDonald D, Hope JT, Prabhakar BS. Upon thyrotropin binding the thyrotropin receptor is internalized and localized to endosome. Endocrinology 2004:145:1003-10.

51. Lahuna O, Quellari M, Achard C, Nola S, Meduri G, Navarro $\mathrm{C}$, et al. Thyrotropin receptor trafficking relies on the hScrib$\beta$ PIX-GIT1-ARF6 pathway. Embo J 2005;24:1364-74.

52. Graves NP, Davies FT. Absence of lutropin (LH) receptor mRNA in the rat thyroid: further evidence for specificity cross-over at the thyroid-stimulating hormone receptor level. Mol Cell Endocrinol 1991;79:21-8.

53. Urizar E, Montanelli L, Loy T, Bonomi M, Swillens S, Gales C, et al. Glycoprotein hormone receptors: link between receptor homodimerization and negative cooperativity. Embo J 2005:24:1954-64.

54. Kraiem Z, Lahat N, Sadeh O, Blithe DL, Nisula BC. Desialylated and deglycosylated human chorionic gonadotropin are superagonists of native human chorionic gonadotropin in human thyroid follicles. Thyroid 1997;7:783-8.

55. Cabrera-Vera TM, Vanhauwe J, Thomas TO, Medkova M, Preininger A, Mazzoni MR, et al. Insights into G protein structure, function, and regulation. Endocr Rev 2003;24:765-81.

56. Laugwitz LK, Allgeier A, Offermanns S, Spicher K, Van Sande J, Dumont JE, et al. The human thyrotropin receptor: a heptahelical receptor capable of stimulating members of all four $G$ protein families. Proc Natl Acad Sci U S A 1996;93:116-20.

57. Jhon DY, Lee HH, Park D, Lee CW, Lee KH, Yoo OJ, et al. Cloning, sequencing, purification, and Gq-dependent activation of phospholipase C- $\beta$ 3. J Biol Chem 1993;268:6654-61.

58. Allgeier A, Offermanns S, Van Sande J, Spicher K, Schultz G, Dumont JE. The human thyrotropin receptor activates G-proteins $\mathrm{Gs}$ and $\mathrm{Gq} / 11$. J Biol Chem 1994;269:13733-5.

59. Newton AC. Regulation of protein kinase C. Curr Opin Cell Biol 1997;9:161-7
60. Gallo A, Benusiglio E, Bonapace IM, Feliciello A, Cassano S, Garbi $C$, et al. v-ras and protein kinase $C$ dedifferentiate thyroid cells by down-regulating nuclear cAMP-dependent protein kinase A. Genes Dev 1992;6:1621-30.

61. Portella G, Vitagliano D, Li Z, Sferratore F, Santoro M, Vecchio $G$, et al. TPA induces a block of differentiation and increases the susceptibility to neoplastic transformation of a rat thyroid epithelial cell line. Oncol Res 1998;10:441-7.

62. Wang JF, Hill DJ, Becks GP. Role of $3^{\prime}, 5^{\prime}$ cyclic adenosine monophosphate and protein kinase $\mathrm{C}$ in the regulation of insulin-like growth factor-binding protein secretion by thyroid-stimulating hormone in isolated ovine thyroid cells. $\mathbf{J}$ Endocrinol 1994;141:231-42

63. D'Arcangelo D, Silletta MG, Di Francesco AL, Bonfitto N, Di Cerbo A, Falasca M, et al. Physiological concentrations of thyrotropin increase cytosolic calcium levels in primary cultures of human thyroid cells. J Clin Endocrinol Metab 1995;80:1136-43.

64. Yanagita $Y$, Okajima F, Sho K, Nagamachi $Y$, Kondo Y. An adenosine derivative cooperates with TSH and Graves' IgG to induce $\mathrm{Ca}^{2+}$ mobilization in single human thyroid cells. Mol Cell Endocrinol 1996;118:47-56.

65. Metcalfe RA, Findlay C, Robertson WR, Weetman AP, Mac Neil S. Differential effect of thyroid-stimulating hormone (TSH) on intracellular free calcium and cAMP in cells transfected with the human TSH receptor. J Endocrinol 1998; 157:415-24.

66. Kobayashi K, Shaver JK, Liang W, Siperstein AE, Duh QY, Clark $\mathrm{OH}$. Increased phospholipase $\mathrm{C}$ activity in neoplastic thyroid membrane. Thyroid 1993;3:25-9.

67. Brabant G, Maenhaut C, Kohrle J, Scheumann G, Dralle H, Hoang-Vu C, et al. Human thyrotropin receptor gene: expression in thyroid tumors and correlation to markers of thyroid differentiation and dedifferentiation. Mol Cell Endocrinol $1991 ; 82: R 7-12$.

68. Broecker M, Mayr GW, Derwah MI. Suppression of thyrotropin receptor-G protein-phospholipase C coupling by activation of protein kinase $C$ in thyroid carcinoma cells. Endocrinology 1997;138:3787-96.

69. Ringel MD, Saji M, Schwindinger WF, Segev D, Zeiger MA Levine MA. Absence of activating mutations of the genes encoding the $\alpha$ subunits of $\mathrm{G} 11$ and $\mathrm{Gq}$ in thyroid neoplasia. J Clin Endocrinol Metab 1998:83:554-9.

70. Cleator JH, Ravenell R, Kurtz DT, Hildebrandt JD. A dominant negative Gas mutant that prevents thyroid-stimulating hormone receptor activation of cAMP production and inositol 1,4,5-trisphosphate turnover: competition by different $\mathrm{G}$ proteins for activation by a common receptor. J Biol Chem 2004;279:36601-7.

71. Sho KM, Okajima F, Abdul Majid M, Kondo $Y$. Reciprocal modulation of thyrotropin actions by P1-purinergic agonists in FRTL-5 thyroid cells. Inhibition of cAMP pathway and stimulation of phospholipase $\mathrm{C}-\mathrm{Ca}^{2+}$ pathway. J Biol Chem 1991;266:12180-4.

72. Laglia G, Zeiger MA, Leipricht A, Caturegli $P$, Levine MA, Kohn LD, et al. Increased cyclic adenosine $3^{\prime}, 5^{\prime}$-monophosphate inhibits $G$ protein-coupled activation of phospholipase $C$ in rat FRTL-5 thyroid cells. Endocrinology 1996; 137:3170-6.

73. Kamiya $Y$, Murakami M, Yanagita $Y$, Koitabashi $H$, Nagamachi $Y$, Hosoi $Y$, et al. Primary culture of cells from hyperfunctioning thyroid adenoma with an activating mutation of Gas. Mol Cell Endocrinol 1998;138:137-42.

74. Ledent C, Denef JF, Cottecchia S, Lefkowitz R, Dumont J, Vassart $\mathrm{G}$, et al. Costimulation of adenylyl cyclase and phospholipase $C$ by a mutant $\alpha-1 B$-adrenergic receptor transgene promotes malignant transformation of thyroid follicular cells. Endocrinology 1997;138:369-78.

75. Rhee SG, Bae YS. Regulation of phosphoinositide-specific phospholipase C isozymes. J Biol Chem 1997:272:15045-8.

76. Sunahara RK, Dessauer CW, Gilman AG. Complexity and diversity of mammalian adenylyl cyclases. Annu Rev Pharmacol Toxicol 1996;36:461-80. 
77. Vanhaesebroeck B, Leevers SJ, Panayotou G, Waterfield MD. Phosphoinositide 3-kinases: a conserved family of signal transducers. Trends Biochem Sci 1997;22:267-72.

78. Holzapfel HP, Bergner B, Wonerow P, Paschke R. Expression of $\mathrm{G} \alpha$ s proteins and TSH receptor signalling in hyperfunctioning thyroid nodules with TSH receptor mutations. Eur $\mathbf{J}$ Endocrinol 2002;147:109-16.

79. Kaupp UB, Seifert R. Cyclic nucleotide-gated ion channels. Physiol Rev 2002:82:769-824.

80. MacKenzie SJ, Baillie GS, McPhee I, MacKenzie C, Seamons $\mathrm{R}$, McSorley $\mathrm{T}$, et al. Long PDE4 cAMP specific phosphodiesterases are activated by protein kinase A-mediated phosphorylation of a single serine residue in Upstream Conserved Region 1 (UCR1). Br J Pharmacol 2002;136:421-33.

81. Dremier S, Vandeput F, Zwartkruis FJ, Bos JL, Dumont JE, Maenhaut $C$. Activation of the small G protein Rap1 in dog thyroid cells by both cAMP-dependent and -independent pathways. Biochem Biophys Res Commun 2000;267:711.

82. Derwahl M, Kuemmel M, Goretzki P, Schatz H, Broecker M. Expression of the human TSH receptor in a human thyroid carcinoma cell line that lacks an endogenous TSH receptor: growth inhibition by cAMP. Biochem Biophys Res Commun 1993; 191:1131-8.

83. Ohta K, Pang XP, Berg L, Hershman JM. Growth inhibition of new human thyroid carcinoma cell lines by activation of adenylate cyclase through the $\beta$-adrenergic receptor. J Clin Endocrinol Metab 1997;82:2633-8.

84. Persani L, Lania A, Alberti L, Romoli R, Mantovani G, Filetti S, et al. Induction of specific phosphodiesterase isoforms by constitutive activation of the cAMP pathway in autonomous thyroid adenomas. J Clin Endocrinol Metab 2000; 85:2872-8.

85. Derwahl M, Manole D, Sobke A, Broecker M. Pathogenesis of toxic thyroid adenomas and nodules: relevance of activating mutations in the TSH-receptor and Gas gene, the possible role of iodine deficiency and secondary and TSH-independent molecular mechanisms. Exp Clin Endocrinol Diabetes 1998;106(suppl 4):S6-9.

86. Kawasaki H, Springett GM, Mochizuki N, Toki S, Nakaya M, Matsuda $M$, et al. A family of cAMP-binding proteins that directly activate Rap1. Science 1998;282:2275-9.

87. Kawasaki H, Springett GM, Toki S, Canales JJ, Harlan P, Blumenstiel JP, et al. A Rap guanine nucleotide exchange factor enriched highly in the basal ganglia. Proc Natl Acad Sci U S A 1998;95:13278-83.

88. Richards JS. New signaling pathways for hormones and cyclic adenosine $3^{\prime}, 5^{\prime}$-monophosphate action in endocrine cells. Mol Endocrinol 2001;15:209-18.

89. Puskas LG, Juhasz F, Zarva A, Hackler L Jr, Farid NR. Gene profiling identifies genes specific for well-differentiated epithelial thyroid tumors. Cell Mol Biol (Noisy-le-grand) 2005:51:177-86.

90. Miller MJ, Rioux L, Prendergast GV, Cannon S, White MA, Meinkoth JL. Differential effects of protein kinase $A$ on Ras effector pathways. Mol Cell Biol 1998;18:3718-26.

91. Ciullo I, Diez-Roux G, Di Domenico M, Migliaccio A, Avvedimento EV. cAMP signaling selectively influences Ras effectors pathways. Oncogene 2001; $20: 1186-92$.

92. Fukushima T, Suzuki S, Mashiko M, Ohtake T, Endo Y, Takebayashi $\mathrm{Y}$, et al. BRAF mutations in papillary carcinomas of the thyroid. Oncogene 2003;22:6455-7.

93. Kimura ET, Nikiforova MN, Zhu Z, Knauf JA, Nikiforov YE, Fagin JA. High prevalence of BRAF mutations in thyroid cancer: genetic evidence for constitutive activation of the RET/PTC-RAS-BRAF signaling pathway in papillary thyroid carcinoma. Cancer Res 2003;63:1454-7.

94. Soares P, Maximo V, Sobrinho-Simões M. Molecular pathology of papillary, follicular and Hurthle cell carcinomas of the thyroid. Arkh Patol 2003;65:45-7.

95. Xu X, Quiros RM, Gattuso P, Ain KB, Prinz RA. High prevalence of BRAF gene mutation in papillary thyroid carcinomas and thyroid tumor cell lines. Cancer Res 2003;63:4561-7.
96. Williams SF, Smallridge RC. Targeting the ERK pathway: novel therapeutics for thyroid cancer. Curr Drug Targets Immune Endocr Metabol Disord 2004;4:199-220.

97. Wong W, Scott JD. AKAP signalling complexes: focal points in space and time. Nat Rev Mol Cell Biol 2004:5:959-70.

98. Calebiro D, de Filippis T, Lucchi S, Martinez F, Porazzi P, Trivellato $R$, et al. Selective modulation of protein kinase $A I$ and II reveals distinct roles in thyroid cell gene expression and growth. Mol Endocrinol 2006;20:3196-211.

99. Kirschner LS, Carney JA, Pack SD, Taymans SE, Giatzakis C, Cho YS, et al. Mutations of the gene encoding the protein kinase A type I-alpha regulatory subunit in patients with the Carney complex. Nat Genet 2000;26:89-92.

100.Woloshin PI, Walton KM, Rehfuss RP, Goodman RH, Cone RD. $3^{\prime}, 5^{\prime}$-cyclic adenosine monophosphate-regulated enhancer binding (CREB) activity is required for normal growth and differentiated phenotype in the FRTL5 thyroid follicular cell line. Mol Endocrinol 1992;6:1725-33.

101.Nguyen LQ, Kopp P, Martinson F, Stanfield K, Roth SI, Jameson JL. A dominant negative CREB (cAMP response elementbinding protein) isoform inhibits thyrocyte growth, thyroidspecific gene expression, differentiation, and function. Mol Endocrinol 2000;14:1448-61.

102.Rosenberg D, Groussin L, Jullian E, Perlemoine K, Bertagna $X$, Bertherat J. Role of the PKA-regulated transcription factor CREB in development and tumorigenesis of endocrine tissues. Ann N Y Acad Sci 2002;968:65-74.

103.Luciani P, Buci L, Conforti B, Tonacchera M, Agretti P, Elisei $\mathrm{R}$, et al. Expression of cAMP response element-binding protein and sodium iodide symporter in benign non-functioning and malignant thyroid tumours. Eur $J$ Endocrinol 2003; 148:579-86.

104.Brunetti A, Chiefari E, Filetti S, Russo D. The 3',5'-cyclic adenosine monophosphate response element binding protein (CREB) is functionally reduced in human toxic thyroid adenomas. Endocrinology 2000;141:722-30.

105.Johannessen M, Delghandi MP, Moens U. What turns CREB on? Cell Signal 2004;16:1211-27.

106.Johannessen M, Moens U. Multisite phosphorylation of the cAMP response element-binding protein (CREB) by a diversity of protein kinases. Front Biosci 2007;12:1814-32.

107.Zhang X, Odom DT, Koo SH, Conkright MD, Canettieri G, Best $\mathrm{J}$, et al. Genome-wide analysis of cAMP-response element binding protein occupancy, phosphorylation, and target gene activation in human tissues. Proc Natl Acad Sci U S A 2005;102:4459-64.

108.Xing M, Usadel H, Cohen Y, Tokumaru Y, Guo Z, Westra WB, et al. Methylation of the thyroid-stimulating hormone receptor gene in epithelial thyroid tumors: a marker of malignancy and a cause of gene silencing. Cancer Res 2003:63:2316-21.

109.Mirebeau-Prunier D, Guyetant S, Rodien P, Franc B, Baris O, Rohmer V, et al. Decreased expression of thyrotropin receptor gene suggests a high-risk subgroup for oncocytic adenoma. Eur J Endocrinol 2004;150:269-76.

110.Fricke-Otto S, Pfarr N, Muhlenberg R, Pohlenz J. Mild congenital primary hypothyroidism in a Turkish family caused by a homozygous missense thyrotropin receptor (TSHR) gene mutation (A593 V). Exp Clin Endocrinol Diabetes 2005; 113:582-5.

111. Matsuo K, Friedman E, Gejman PV, Fagin JA. The thyrotropin receptor (TSH-R) is not an oncogene for thyroid tumors: structural studies of the TSH-R and the alpha-subunit of Gs in human thyroid neoplasms. J Clin Endocrinol Metab 1993:76:1446-51.

112.Krohn K, Paschke R. Somatic mutations in thyroid nodular disease. Mol Genet Metab 2002;75:202-8.

113. Rodien P, Ho SC, Vlaeminck V, Vassart G, Costagliola S. Activating mutations of TSH receptor. Ann Endocrinol (Paris) 2003;64:12-6.

114.Duprez L, Parma J, Van Sande J, Allgeier A, Leclere J, Schvartz $C$, et al. Germline mutations in the thyrotropin receptor gene cause non-autoimmune autosomal dominant hyperthyroidism. Nat Genet 1994;7:396-401. 
115.Tonacchera M, Van Sande J, Cetani F, Swillens S, Schvartz C, Winiszewski $P$, et al. Functional characteristics of three new germline mutations of the thyrotropin receptor gene causing autosomal dominant toxic thyroid hyperplasia. J Clin Endocrinol Metab 1996;81:547-54.

116. Russo D, Arturi F, Chiefari E, Filetti S. Molecular insights into TSH receptor abnormality and thyroid disease. J Endocrinol Invest 1997;20:36-47.

117.Arturi F, Capula C, Chiefari E, Filetti S, Russo D. Thyroid hyperfunctioning adenomas with and without Gsp/TSH receptor mutations show similar clinical features. Exp Clin Endocrinol Diabetes 1998;106:234-6.

118.Russo D, Arturi F, Wicker R, Chazenbalk GD, Schlumberger $M$, DuVillard JA, et al. Genetic alterations in thyroid hyperfunctioning adenomas. J Clin Endocrinol Metab 1995;80:1347-51.

119.Russo D, Tumino S, Arturi F, Vigneri P, Grasso G, Pontecorvi $A$, et al. Detection of an activating mutation of the thyrotropin receptor in a case of an autonomously hyperfunctioning thyroid insular carcinoma. J Clin Endocrinol Metab 1997;82:735-8.

120. Russo D, Wong MG Costante G, Chiefari E, Treseler PA, Arturi $\mathrm{F}$, et al. A Val 677 activating mutation of the thyrotropin receptor in a Hurthle cell thyroid carcinoma associated with thyrotoxicosis. Thyroid 1999;9:13-7.

121.Spambalg D, Sharifi N, Elisei R, Gross JL, Medeiros-Neto G, Fagin JA. Structural studies of the thyrotropin receptor and Gs alpha in human thyroid cancers: low prevalence of mutations predicts infrequent involvement in malignant transformation. J Clin Endocrinol Metab 1996:81:3898-901.

122.Esapa C, Foster S, Johnson S, Jameson JL, Kendall-Taylor P, Harris PE. G protein and thyrotropin receptor mutations in thyroid neoplasia. J Clin Endocrinol Metab 1997:82:493-6.

123.Cetani F, Tonacchera M, Pinchera A, Barsacchi R, Basolo F, Miccoli $P$, et al. Genetic analysis of the TSH receptor gene in differentiated human thyroid carcinomas. J Endocrinol Invest 1999;22:273-8.

124.Camacho P, Gordon D, Chiefari E, Yong S, DeJong S, Pitale $\mathrm{S}$, et al. A Phe 486 thyrotropin receptor mutation in an autonomously functioning follicular carcinoma that was causing hyperthyroidism. Thyroid 2000;10:1009-12.

125.Corvilain B, Van Sande J, Dumont JE, Vassart G. Somatic and germline mutations of the TSH receptor and thyroid diseases. Clin Endocrinol (Oxf) 2001;55:143-58.

126.Kopp P, Van Sande J, Parma J, Duprez L, Gerber H, Joss E, et al. Brief report: congenital hyperthyroidism caused by a mutation in the thyrotropin-receptor gene. N Engl J Med 1995;332:150-4.

127.de Roux N, Polak M, Couet J, Leger J, Czernichow P, Milgrom $E$, et al. A neomutation of the thyroid-stimulating hormone receptor in a severe neonatal hyperthyroidism. J Clin Endocrinol Metab 1996;81:2023-6.

128.Fuhrer D, Holzapfel HP, Wonerow P, Scherbaum WA, Paschke $R$. Somatic mutations in the thyrotropin receptor gene and not in the $\mathrm{G} \alpha$ s protein gene in 31 toxic thyroid nodules. J Clin Endocrinol Metab 1997;82:3885-91.

129. Holzapfel HP Fuhrer D, Wonerow P Weinland G, Scherbaum WA, Paschke R. Identification of constitutively activating somatic thyrotropin receptor mutations in a subset of toxic multinodular goiters. J Clin Endocrinol Metab 1997;82:4229-33.

130.Tonacchera M, Agretti P, Chiovato L, Rosellini V, Ceccarini G, Perri $A$, et al. Activating thyrotropin receptor mutations are present in nonadenomatous hyperfunctioning nodules of toxic or autonomous multinodular goiter. J Clin Endocrinol Metab 2000;85:2270-4.

131.Karges B, Krause G, Homoki J, Debatin KM, de Roux N Karges W. TSH receptor mutation V509A causes familial hyperthyroidism by release of interhelical constraints between transmembrane helices TMH3 and TMH5. J Endocrinol 2005;186:377-85.

132.Learoyd DL, Messina M, Zedenius J, Robinson BG. Molecular genetics of thyroid tumors and surgical decision-making. World J Surg 2000;24:923-33.
133.Trulzsch B, Krohn K, Wonerow P, Chey S, Holzapfel HP, Ackermann $F$, et al. Detection of thyroid-stimulating hormone receptor and Gas mutations: in 75 toxic thyroid nodules by denaturing gradient gel electrophoresis. J Mol Med 2001;78:684-91.

134. Farid NR, Kascur V, Balazs C. The human thyrotropin receptor is highly mutable: a review of gain-of-function mutations. Eur J Endocrinol 2000;143:25-30.

135.Al-Khafaji F, Wiltshire M, Fuhrer D, Mazziotti G, Lewis MD, Smith PJ, et al. Biological activity of activating thyrotrophin receptor mutants: modulation by iodide. J Mol Endocrinol 2005;34:209-20.

136. Ho SC, Van Sande J, Lefort A, Vassart G, Costagliola S. Effects of mutations involving the highly conserved S281 HCC motif in the extracellular domain of the thyrotropin (TSH) receptor on TSH binding and constitutive activity. Endocrinology 2001;142:2760-7.

137. Biebermann H, Schoneberg T, Hess C, Germak J, Gudermann $\mathrm{T}$, Gruters A. The first activating TSH receptor mutation in transmembrane domain 1 identified in a family with nonautoimmune hyperthyroidism. J Clin Endocrinol Metab 2001;86:4429-33.

138.Elgadi A, Arvidsson CG, Janson A, Marcus C, Costagliola S, Norgren S. Autosomal-dominant non-autoimmune hyperthyroidism presenting with neuromuscular symptoms. Acta Paediatr 2005;94:1145-8.

139.Arturi F, Chiefari E, Tumino S, Russo D, Squatrito S, Chazenbalk $G$, et al. Similarities and differences in the phenotype of members of an Italian family with hereditary non-autoimmune hyperthyroidism associated with an activating TSH receptor germline mutation. J Endocrinol Invest 2002;25:696-701.

140.Parma J, Van Sande J, Swillens S, Tonacchera M, Dumont J, Vassart G. Somatic mutations causing constitutive activity of the thyrotropin receptor are the major cause of hyperfunctioning thyroid adenomas: identification of additional mutations activating both the cyclic adenosine $3^{\prime}, 5^{\prime}$-monophosphate and inositol phosphate- $\mathrm{Ca}^{2+}$ cascades. Mol Endocrinol 1995;9:725-33.

141.Kosugi S, Hai N, Okamoto H, Sugawa H, Mori T. A novel activating mutation in the thyrotropin receptor gene in an autonomously functioning thyroid nodule developed by a Japanese patient. Eur J Endocrinol 2000;143:471-7.

142.Vaidya B, Campbell V, Tripp JH, Spyer G, Hattersley AT, Ellard S. Premature birth and low birth weight associated with nonautoimmune hyperthyroidism due to an activating thyrotropin receptor gene mutation. Clin Endocrinol (Oxf) 2004:60:711-8.

143.Gozu H, Avsar M, Bircan R, Sahin S, Ahiskanali R, Gulluoglu $\mathrm{B}$, et al. Does a Leu 512 Arg thyrotropin receptor mutation cause an autonomously functioning papillary carcinoma? Thyroid 2004;14:975-80.

144.Sykiotis GP, Sgourou A, Papachatzopoulou A, Markou KB, Kyriazopoulou V, Papavassiliou AG, et al. A somatic mutation in the thyrotropin receptor gene in a patient with an autonomous nodule within a multinodular goiter. Hormones (Athens) 2002:1:42-6.

145. Nishihara E, Fukata S, Hishinuma A, Kudo T, Ohye H, Ito M, et al. Sporadic congenital hyperthyroidism due to a germline mutation in the thyrotropin receptor gene (Leu $512 \mathrm{GIn}$ ) in a Japanese patient. Endocr J 2006;53:735-40.

146.Claus M, Maier J, Paschke R, Kujat C, Stumvoll M, Fuhrer D. Novel thyrotropin receptor germline mutation (Ile568Val) in a Saxonian family with hereditary nonautoimmune hyperthyroidism. Thyroid 2005;15:1089-94.

147.Alberti L, Proverbio MC, Costagliola S, Weber G, Beck-Peccoz $\mathrm{P}$, Chiumello $\mathrm{G}$, et al. A novel germline mutation in the TSH receptor gene causes non-autoimmune autosomal dominant hyperthyroidism. Eur J Endocrinol 2001;145:249-54.

148.Wonerow P, Schoneberg T, Schultz G, Gudermann T, Paschke R. Deletions in the third intracellular loop of the thyrotropin receptor. A new mechanism for constitutive activation. J Biol Chem 1998;273:7900-5. 
149. Niepomniszcze H, Suarez H, Pitoia F, Pignatta A, Danilowicz $\mathrm{K}$, Manavela $\mathrm{M}$, et al. Follicular carcinoma presenting as autonomous functioning thyroid nodule and containing an activating mutation of the TSH receptor (T620I) and a mutation of the Ki-RAS (G12C) genes. Thyroid 2006;16:497-503.

150.Ludgate M, Gire V, Crisp M, Ajjan R, Weetman A, Ivan M, et al. Contrasting effects of activating mutations of $G \alpha$ s and the thyrotropin receptor on proliferation and differentiation of thyroid follicular cells. Oncogene 1999;18:4798-807.

151.Gozu H, Avsar M, Bircan R, Claus M, Sahin S, Sezgin O, et al. Two novel mutations in the sixth transmembrane segment of the thyrotropin receptor gene causing hyperfunctioning thyroid nodules. Thyroid 2005;15:389-97.

152.Gozu H, Avsar M, Bircan R, Sahin S, Deyneli O, Cirakoglu B, et al. Mutations in the thyrotropin receptor signal transduction pathway in the hyperfunctioning thyroid nodules from multinodular goiters: a study in the Turkish population. Endocr J 2005;52:577-85.

153. Nwosu BU, Gourgiotis L, Gershengorn MC, Neumann S. A novel activating mutation in transmembrane helix 6 of the thyrotropin receptor as cause of hereditary nonautoimmune hyperthyroidism. Thyroid 2006;16:505-12.

154.Fuhrer D, Tannapfel A, Sabri O, Lamesch P, Paschke R. Two somatic TSH receptor mutations in a patient with toxic metastasising follicular thyroid carcinoma and non-functional lung metastases. Endocr Relat Cancer 2003;10:591-600.

155.Voigt C, Holzapfel H, Paschke R. Expression of $\beta$-arrestins in toxic and cold thyroid nodules. FEBS Lett 2000;486:208-12.

156.Van Keymeulen A, Roger PP, Dumont JE, Dremier S. TSH and cAMP do not signal mitogenesis through Ras activation. Biochem Biophys Res Commun 2000;273:154-8.

157. Frasca F, Pandini G, Scalia P, Sciacca L, Mineo R, Costantino $A$, et al. Insulin receptor isoform $A$, a newly recognized, highaffinity insulin-like growth factor II receptor in fetal and cancer cells. Mol Cell Biol 1999;19:3278-88.

158.o K, Yamazaki K, Shizume K, Kanaji Y, Obara T, Ohsumi K, et al. Stimulation by thyroid-stimulating hormone and Grave's immunoglobulin $\mathrm{G}$ of vascular endothelial growth factor mRNA expression in human thyroid follicles in vitro and flt mRNA expression in the rat thyroid in vivo. J Clin Invest 1995;96:1295-302.

159.Belfiore A, Russo D, Vigneri R, Filetti S. Graves' disease, thyroid nodules and thyroid cancer. Clin Endocrinol (Oxf) 2001:55:711-8.

160.Mitsutake N, Miyagishi M, Mitsutake S, Akeno N, Mesa C Jr, Knauf JA, et al. BRAF mediates RET/PTC-induced mitogenactivated protein kinase activation in thyroid cells: functional support for requirement of the RET/PTC-RAS-BRAF pathway in papillary thyroid carcinogenesis. Endocrinology 2006; 147:1014-9.

161.Groussin L, Fagin JA. Significance of BRAF mutations in papillary thyroid carcinoma: prognostic and therapeutic implications. Nat Clin Pract Endocrinol Metab 2006;2:180-1.

162. Ouyang B, Knauf JA, Smith EP, Zhang L, Ramsey T, Yusuff N et al. Inhibitors of Raf kinase activity block growth of thyroid cancer cells with RET/PTC or BRAF mutations in vitro and in vivo. Clin Cancer Res 2006;12:1785-93.

163. Fagin JA. How thyroid tumors start and why it matters: kinase mutants as targets for solid cancer pharmacotherapy. J Endocrinol 2004:183:249-56.

164.Dumaz N, Marais R. Integrating signals between cAMP and the RAS/RAF/MEK/ERK signalling pathways. Based on the anniversary prize of the Gesellschaft fur Biochemie und Molekularbiologie Lecture delivered on 5 July 2003 at the Special FEBS Meeting in Brussels. Febs J 2005;272:3491-504.

165.Bongarzone I, Butti MG, Coronelli S, Borrello MG, Santoro M, Mondellini $\mathrm{P}$, et al. Frequent activation of ret protooncogene by fusion with a new activating gene in papillary thyroid carcinomas. Cancer Res 1994;54:2979-85.

166. Iacovelli L, Capobianco L, Salvatore L, Sallese M, D'Ancona GM, De Blasi A. Thyrotropin activates mitogen-activated protein kinase pathway in FRTL-5 by a cAMP-dependent protein kinase A-independent mechanism. Mol Pharmacol 2001;60:924-33.
167.Vandeput F, Perpete S, Coulonval K, Lamy F, Dumont JE. Role of the different mitogen-activated protein kinase subfamilies in the stimulation of dog and human thyroid epithelial cell proliferation by cyclic adenosine $5^{\prime}$-monophosphate and growth factors. Endocrinology 2003;144:1341-9.

168. Mandal M, Kim S, Younes MN, Jasser SA, El-Naggar AK, Mills GB, et al. The Akt inhibitor KP372-1 suppresses Akt activity and cell proliferation and induces apoptosis in thyroid cancer cells. Br J Cancer 2005;92:1899-905.

169.Garcia-Rostan G, Costa AM, Pereira-Castro I, Salvatore G, Hernandez R, Hermsem MJ, et al. Mutation of the PIK3CA gene in anaplastic thyroid cancer. Cancer Res 2005; 65:10199-207.

170.Frisk T, Foukakis T, Dwight T, Lundberg J, Hoog A, Wallin G, et al. Silencing of the PTEN tumor-suppressor gene in anaplastic thyroid cancer. Genes Chromosomes Cancer 2002;35:74-80.

171.Xing M. Gene methylation in thyroid tumorigenesis. Endocrinology 2007;148(3):948-53.

172.Puxeddu E, Zhao G, Stringer JR, Medvedovic M, Moretti S, Fagin JA. Characterization of novel non-clonal intrachromosomal rearrangements between the $\mathrm{H} 4$ and PTEN genes (H4/PTEN) in human thyroid cell lines and papillary thyroid cancer specimens. Mutat Res 2005;570:17-32.

173.Schagdarsurengin U, Gimm O, Dralle H, Hoang-Vu C, Dammann R. CpG island methylation of tumor-related promoters occurs preferentially in undifferentiated carcinoma. Thyroid 2006;16:633-42.

174.Weng LP, Gimm O, Kum JB, Smith WM, Zhou XP, WynfordThomas D, et al. Transient ectopic expression of PTEN in thyroid cancer cell lines induces cell cycle arrest and cell typedependent cell death. Hum Mol Genet 2001;10:251-8.

175. Lee IS, Hur EM, Suh BC, Kim MH, Koh DS, Rhee IJ, et al. Protein kinase $\mathrm{A}$ - and $\mathrm{C}$-induced insulin release from $\mathrm{Ca}^{2+}$-insensitive pools. Cell Signal 2003;15:529-37.

176.De Gregorio G, Coppa A, Cosentino C, Ucci S, Messina S, Nicolussi $A$, et al. The p85 regulatory subunit of PI3K mediates TSH-cAMP-PKA growth and survival signals. Oncogene 2007;26(14):2039-47.

177.De Falco V, Guarino V, Malorni L, Cirafici AM, Troglio F, Erreni $\mathrm{M}$, et al. RAI(ShcC/N-Shc)-dependent recruitment of GAB 1 to RET oncoproteins potentiates PI 3-K signalling in thyroid tumors. Oncogene 2005;24:6303-13.

178.Graff JR, Greenberg VE, Herman JG, Westra WH, Boghaert $E R$, Ain KB, et al. Distinct patterns of E-cadherin CpG island methylation in papillary, follicular, Hurthle's cell, and poorly differentiated human thyroid carcinoma. Cancer Res 1998;58:2063-6.

179. Kurihara K, Shimizu S, Chong J, Hishima T, Funata N, Kashiwagi $\mathrm{H}$, et al. Nuclear localization of immunoreactive $\beta$-catenin is specific to familial adenomatous polyposis in papillary thyroid carcinoma. Jpn J Cancer Res 2000; 91:1100-2.

180.Garcia-Rostan G, Camp RL, Herrero A, Carcangiu ML, Rimm DL, Tallini G. $\beta$-catenin dysregulation in thyroid neoplasms: down-regulation, aberrant nuclear expression, and CTNNB1 exon 3 mutations are markers for aggressive tumor phenotypes and poor prognosis. Am J Pathol 2001; 158:987-96.

181.Nikiforov YE. Genetic alterations involved in the transition from well-differentiated to poorly differentiated and anaplastic thyroid carcinomas. Endocr Pathol 2004;15:319-27.

182.Rocha AS, Soares P, Seruca R, Maximo V, Matias-Guiu X, Cameselle-Teijeiro $J$, et al. Abnormalities of the $E$ cadherin/catenin adhesion complex in classical papillary thyroid carcinoma and in its diffuse sclerosing variant. J Pathol 2001;194:358-66.

183. Chen AE, Ginty DD, Fan CM. Protein kinase A signalling via CREB controls myogenesis induced by Wnt proteins. Nature 2005;433:317-22.

184. Hino S, Tanji C, Nakayama KI, et al. Phosphorylation of $\beta$ catenin by cyclic AMP-dependent protein kinase stabilizes $\beta$ catenin through inhibition of its ubiquitination. Mol Cell Biol 2005;25:9063-72. 
185.Rao AS, Kremenevskaja N, Resch J, Brabant G. Lithium stimulates proliferation in cultured thyrocytes by activating

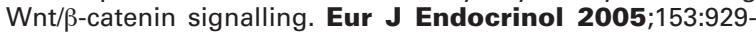
38.

186.Lantsov D, Meirmanov S, Nakashima M, Kondo H, Saenko $\mathrm{V}$, Naruke $\mathrm{Y}$, et al. Cyclin D1 overexpression in thyroid papillary microcarcinoma: its association with tumour size and aberrant $\beta$-catenin expression. Histopathology 2005; 47:248-56.

187. Nagayama Y, Shigematsu K, Namba H, Zeki K, Yamashita S, Niwa M. Inhibition of angiogenesis and tumorigenesis, and induction of dormancy by p53 in a p53-null thyroid carcinoma cell line in vivo. Anticancer Res 2000;20:2723-8.

188.Paron I, D'Ambrosio C, Scaloni A, Berlingieri MT, Pallante PL, Fusco $A$, et al. A differential proteomic approach to identify proteins associated with thyroid cell transformation. J Mol Endocrinol 2005;34:199-207. 189.de Capoa A, Grappelli C, Volpino P, Bononi M, Musolino A, Ciardi $A$, et al. Nuclear methylation levels in normal and cancerous thyroid cells. Anticancer Res 2004;24:1495-500.

190. Foukakis T, Au AY, Wallin G, Geli J, Forsberg L, Clifton-Bligh $R$, et al. The Ras effector NORE1A is suppressed in follicular thyroid carcinomas with a PAX8-PPAR $\gamma$ fusion. J Clin Endocrinol Metab 2006;91:1143-9.

Address for correspondence:

Pilar Santisteban

Instituto de Investigaciones Biomédicas

CSIC-UAM

Arturo Duperier 4

28029 Madrid (Spain)

Fax: (3491) 585-4401

Email: psantisteban@iib.uam.es 